\title{
Impact of anthropogenic emission on air quality over a megacity - revealed from an intensive atmospheric campaign during the Chinese Spring Festival
}

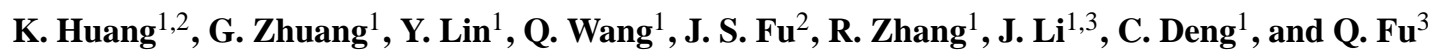 \\ ${ }^{1}$ Center for Atmospheric Chemistry Study, Department of Environmental Science and Engineering, Fudan University, \\ Shanghai, 200433, China \\ ${ }^{2}$ Department of Civil and Environmental Engineering, The University of Tennessee, Knoxville, TN 37996, USA \\ ${ }^{3}$ Shanghai Environmental Monitoring Center, Shanghai, 200030, China \\ Correspondence to: G. Zhuang (gzhuang@fudan.edu.cn) and J. S. Fu (jsfu@ utk.edu)
}

Received: 28 May 2012 - Published in Atmos. Chem. Phys. Discuss.: 12 July 2012

Revised: 5 November 2012 - Accepted: 17 November 2012 - Published: 5 December 2012

\begin{abstract}
The Chinese Spring Festival is one of the most important traditional festivals in China. The peak transport in the Spring Festival season (spring travel rush) provides a unique opportunity for investigating the impact of human activity on air quality in the Chinese megacities. Emission sources are varied and fluctuate greatly before, during and after the Festival. Increased vehicular emissions during the "spring travel rush" before the 2009 Festival resulted in high level pollutants of $\mathrm{NO}_{\mathrm{x}}\left(270 \mu \mathrm{g} \mathrm{m}^{-3}\right)$, $\mathrm{CO}\left(2572 \mu \mathrm{g} \mathrm{m}^{-3}\right)$, black carbon (BC) $\left(8.5 \mu \mathrm{g} \mathrm{m}^{-3}\right)$ and extremely low single scattering albedo of 0.76 in Shanghai, indicating strong, fresh combustion. Organics contributed most to $\mathrm{PM}_{2.5}$, followed by $\mathrm{NO}_{3}^{-}, \mathrm{NH}_{4}^{+}$, and $\mathrm{SO}_{4}^{2-}$. During the Chinese Lunar New Year's Eve and Day, widespread usage of fireworks caused heavy pollution of extremely high aerosol concentration, scattering coefficient, $\mathrm{SO}_{2}$, and $\mathrm{NO}_{\mathrm{x}}$. Due to the "spring travel rush" after the festival, anthropogenic emissions gradually climbed and mirrored corresponding increases in the aerosol components and gaseous pollutants. Secondary inorganic aerosol $\left(\mathrm{SO}_{4}^{2-}, \mathrm{NO}_{3}^{-}\right.$, and $\left.\mathrm{NH}_{4}^{+}\right)$accounted for a dominant fraction of $74 \%$ in $\mathrm{PM}_{2.5}$ due to an increase in human activity. There was a greater demand for energy as vast numbers of people using public transportation or driving their own vehicles returned home after the Festival. Factories and constructions sites were operating again.

The potential source contribution function (PSCF) analysis illustrated the possible source areas for air pollutants of Shanghai. The effects of regional and long-range trans-
\end{abstract}

port were both revealed. Five major sources, i.e. natural sources, vehicular emissions, burning of fireworks, industrial and metallurgical emissions, and coal burning were identified using the principle component analysis. The average visibility during the whole study period was less than $6 \mathrm{~km}$. It had been estimated that $50 \%$ of the total light extinction was due to the high water vapor in the atmosphere. This study demonstrates that organic aerosol was the largest contributor to aerosol extinction at $47 \%$, followed by sulfate ammonium, nitrate ammonium, and $\mathrm{EC}$ at $22 \%, 14 \%$, and $12 \%$, respectively. Our results indicated the dominant role of traffic-related aerosol species (i.e. organic aerosol, nitrate and EC) on the formation of air pollution, and suggested the importance of controlling vehicle numbers and emissions in mega-cities of China as its population and economy continue to grow.

\section{Introduction}

China is currently playing an important role in the global economic growth and renaissance. The expansion of the urban population has resulted in tremendous increases in energy consumption, emissions of air pollutants and bad air quality days in megacities, city clusters, and their immediate vicinities. Air pollution has become one of the top environmental concerns in China. Tropospheric $\mathrm{NO}_{2}$ column over China has experienced a large growth over Eastern China, especially

Published by Copernicus Publications on behalf of the European Geosciences Union. 
above the industrial areas with a fast economical growth (van der $\mathrm{A}$ et al., 2006). Although $\mathrm{PM}_{10}$ index was trending down (Chan and Yao, 2008), some aerosol components such as black carbon (BC) and organic carbon increased since 2000 based on an anthropogenic emission inventory of China developed for 1990-2005 (Lei et al., 2011). Fossil-fuel combustion is the main source for BC in East Asia (Zhang et al., 2009). The heating rate from fossil fuel containing BC is about $100 \%$ larger than biomass burning containing $\mathrm{BC}$, and Asia was also subject to large ratio of $\mathrm{BC}$-to- $\mathrm{SO}_{2}$ emissions, an index for the net warming (Ramana et al., 2010). As many developing countries and regions are becoming more industrialized, emissions of air pollutants are likely to increase dramatically. Hence, there is a great need to implement control measures to improve air quality and protect public health.

The Yangtze River Delta, Beijing, and the Pearl River Delta are the most economically vibrant regions in China. $\mathrm{SO}_{2}$ emission from the coal-fired power sector was projected to decrease since 2005 , attributed mainly to the wide application of the flue gas desulfurization (FGD) technology (Zhao et al., 2008). The surface annual $\mathrm{SO}_{2}$ concentration was also observed to decrease after 2005 in Shanghai due to the closing of dirty and inefficient power plant units and the implementation of new technology (Lin et al., 2012). It has been suggested that controlling emissions from industrial facilities and operating vehicles was an efficient way to reduce $\mathrm{SO}_{2}$, $\mathrm{NO}_{\mathrm{x}}$, NMVOC and $\mathrm{PM}_{10}$ during the 2008 Beijing Olympic Games (Wang et al., 2010). A model study using the Model3/CMAQ (Community Multi-scale Air Quality) stated that upgrading to National IV emission standards would effectively reduce daily averaged $\mathrm{NO}_{2}$ and $\mathrm{PM}_{10}$ concentrations by $11.7 \mathrm{ppbv}$ and $21.3 \mathrm{\mu g} \mathrm{m}^{-3}$ for the Pearl River Delta region (Che et al., 2011).

Shanghai is China's most populated urban area and has a total residential population of about 23 million. Approximately 9 million people are temporary residents from the other provinces and cities, which accounts for $39 \%$ of Shanghai's total population (SMSB, 2011). Emission sources of Shanghai were complicated to evaluate because of the variety, type, and the times they were most heavily used. The typical causes for haze formation were investigated and determined to be derived from secondary inorganic pollution, dust, and biomass burning (Huang et al., 2012). In this study, we conducted an intensive field campaign in Shanghai around the Chinese Spring Festival (Lunar New Year) travel season in 2009, which is also referred to as "Chunyun" in Chinese or the "spring travel rush". During this period, extremely high traffic inflows and outflows occur as numerous migrant residents return to their hometowns to reunite with their families and celebrate the traditional Chinese Spring Festival. The transport system, e.g. trains, airplanes, and buses, experience tremendous challenges. In 2009, the total number of journeys during the "spring travel rush" reached $\sim 23$ billion, which exceeded the entire population of China. It was estimated that approximately 21 million people chose to travel by roads. Thus, the Chinese New Year exodus is regarded as the world's largest annual migration (BBC, 2009). The emission sources are expected to vary greatly during this time due to tremendous fluctuations in human activity. Different from previous studies aiming to characterize the physical, chemical and optical features of haze in Shanghai (Fu et al., 2008; He et al., 2012; Huang et al., 2012; Wang et al., 2006), this study evaluated the impact of anthropogenic emission (e.g. vehicular and industrial emission) variations on the aerosol chemical composition, optical properties and the atmospheric visibility through a "virtual atmospheric experiment". Our previous research results indicate that the traffic restrictions on the World Carfree days (22 September) in multi-years over Shanghai had little positive effect on the air quality. This was because the control measures implemented on both time durations and restriction areas were very limited (J. Li, personal communication, 2010). While in this study, the long Spring Festival travel season provided us with a unique opportunity to evaluate these effects. To our knowledge, reports on the impact of emission variations on air quality in megacities prior to, during and after the Chinese Spring festival were infrequent.

\section{Methodology}

\subsection{Observational site}

The observational site $\left(31.3^{\circ} \mathrm{N}, 121.5^{\circ} \mathrm{E}\right)$ in this study was on the roof ( $\sim 20 \mathrm{~m}$ high) of a teaching building on the campus of Fudan University in Yangpu district of Shanghai. Almost no high buildings are around this sampling site. This observational site is approximately $40 \mathrm{~km}$ inland from the East China Sea. About 1.3 million residents are living in this area (SMSB, 2011). The daily concentrations of $\mathrm{SO}_{2}, \mathrm{NO}_{2}$, and $\mathrm{PM}_{10}$ measured in our monitoring site during this study period had consistent temporal variation and similar magnitudes to the reported data of the whole Shanghai metropolitan area from Shanghai Environmental Monitoring Center (http: //www.envir.gov.cn/airnews/) as shown in Fig. S1. Thus, this site could be regarded as a representative of the megacity Shanghai, standing for the mixing of residential, traffic, construction, and industrial sources.

\subsection{Aerosol, trace gases, and visibility measurement}

The Thermo Scientific TEOM 1405-D monitor simultaneously measured $\mathrm{PM}_{2.5}$, PM-Coarse $\left(\mathrm{PM}_{10-2.5}\right)$ and $\mathrm{PM}_{10}$ mass concentration upon an oscillating balance. Particulate matters accumulating on a filter mounted changes in the frequency of oscillation, which were related to the mass of material accumulating on the filter, were detected in quasireal time and converted by a microprocessor into an equivalent PM mass concentration every few seconds, as a $10 \mathrm{~min}$ running average. Sampler split a $\mathrm{PM}_{10}$ sample stream into its fine $\left(\mathrm{PM}_{2.5}\right)$ and coarse $\left(\mathrm{PM}_{10-2.5}\right)$ fractions using a 
USEPA-designed virtual impactor for the additional $2.5 \mu \mathrm{m}$ cutpoint. The total flow rate operated at $16.67 \mathrm{~L} \mathrm{~min}^{-1}$, and two separate flow controllers maintained the coarse particle stream at $1.67 \mathrm{~L} \mathrm{~min}^{-1}$ and the fine particle stream at 3.0 $\mathrm{L} \mathrm{min}^{-1}$. The instrument was operated at a temperature of $50^{\circ} \mathrm{C}$ to avoid the interference of moisture on the calculation of aerosol concentrations. PM concentrations were averaged and used at intervals of $1 \mathrm{~h}$ in this study. Trace gases instruments included $43 \mathrm{i} \mathrm{SO}$ analyzer, $42 \mathrm{i} \mathrm{NO}-\mathrm{NO}_{2}-\mathrm{NO}_{\mathrm{x}}$ analyzer, $49 \mathrm{i}_{3}$ analyzer and $48 \mathrm{i} \mathrm{CO}$ analyzer. Some measures were implemented to eliminate the potential interference of $\mathrm{NO}_{\mathrm{y}}$ species on $\mathrm{NO}_{2}$ measurements as much as possible, e.g. using a filter and subtracting the concentration of HONO. The routine QA/QC included the daily zero/standard calibration, span and range check, station environmental control, staff certification, etc., according to the Technical Guideline of Automatic Stations of Ambient Air Quality in Shanghai based on the national specification HJ/T193-2005, which was developed following the technical guidance established by the US Environmental Protection Agency (USEPA, 1998). The multi-point calibrations were applied upon initial installation of the instruments at the routine intervals of every week. And the two-point calibrations were applied on a daily basis. Visibility was measured by using a Vaisala Present Weather Detector (Model: FD12P). Its sensor, which combined the functions of a forward scatter visibility meter and a present weather sensor, could measure visibility (meteorological optical range, MOR), precipitation intensity, and precipitation type. The detector measured visibility by using the principle of forward scatter measurement within a range of 10-50000 m (Vaisala, 2002).

\subsection{Measurement of aerosol optical properties}

\subsubsection{Aerosol scattering coefficient measurement}

A nephelometer (EcoTech, M9003) was used to continuously measure the aerosol scattering coefficient $\left(\sigma_{\mathrm{sp}}\right)$ at the wavelength of $520 \mathrm{~nm}$. It has a detection limit of less than $0.3 \mathrm{M} \mathrm{m}^{-1}$ with $60 \mathrm{~s}$ integration and a light scattering angle of $10-170^{\circ}$. Correction factors from Anderson and Ogren (1998) were used to account for the forward scattering within the angle of $0-10^{\circ}$. Air was pumped at a flow rate of $5 \mathrm{~L} \mathrm{~min}^{-1}$ into a heating system. The processor-controlled heating system automatically maintained the relative humidity in the chamber below $40 \%$. Zero calibrations were performed daily with particle-free air to subtract the Rayleigh scattering from the total light scattering coefficient. Span calibrations were performed daily using $99.99 \% \mathrm{CO}_{2}$.

\subsubsection{Black carbon (aerosol absorption coefficient) measurement}

An aethalometer (AE-21, Magee Scientific Co.) equipped with a $\mathrm{PM}_{2.5}$ inlet impactor was used to continuously mea- sure the concentration of $\mathrm{BC}$ (black carbon) at the wavelength of 880 and $370 \mathrm{~nm}$. The aethalometer measures BC concentrations by collecting the particles on a rolled quartz filter with a cellulose fiber backing, and continuously monitoring the transmission intensity of light beams at 880 and $370 \mathrm{~nm}$ wavelengths. The theory of calculating BC concentration could be found elsewhere (Magee-Scientific, 2005). Due to known issues of multiple scattering and filter loading problems, the calculated aerosol absorption coefficient was corrected by using an empirical correction method proposed by Arnott et al. (2005).

$B_{\mathrm{abs}, n}=\frac{\mathrm{SGBC}_{n}-\alpha B_{\mathrm{sca}, n}}{M} \sqrt{1+\frac{\left(\frac{V \mathrm{~d} t}{A}\right) \sum_{i=1}^{n-1} B_{\mathrm{abs}, i}}{\tau_{a, f x}}}$,

where $n$ represents the $n$-th measurement of BC. $V$ is the flow rate, $\mathrm{d} t$ is the measurement interval, and $A$ is the filter area. SG, $\alpha, M$, and $\tau_{\alpha, f x}$ are empirical values that are listed in a lookup table in Arnott et al. (2005). As the aerosol scattering coefficient was obtained at $520 \mathrm{~nm}$ as stated above, we have to convert $\sigma_{\mathrm{ap}}$ to its values at $520 \mathrm{~nm}$ from the Angstrom absorption exponent $\delta_{\text {ap }}, \delta_{\text {ap }}=-\operatorname{dlog}\left(\sigma_{\text {ap }}\right) / \mathrm{d} \log (\lambda)$. The $\delta_{\text {ap }}$ thus obtained was used in the Angstrom relation $\left(\delta_{\text {ap }}(\lambda)=\right.$ $\beta_{\mathrm{ap}} \lambda^{-\delta}$ ) to obtain the absorption coefficient at required wavelength. Then we can obtain the aerosol absorption coefficient and scattering coefficient at the same wavelength of $520 \mathrm{~nm}$. The single scattering albedo (SSA) can be calculated using $\omega=\sigma_{\mathrm{sp}} /\left(\sigma_{\mathrm{ap}}+\sigma_{\mathrm{sp}}\right)$.

\subsection{Manual sampling}

Aerosol samples of TSP and $\mathrm{PM}_{2.5}$ were collected on Whatman 41 filters (Whatman Inc., Maidstone, UK) using medium-volume samplers manufactured by Beijing Geological Instrument-Dickel Co., Ltd. (model: TSP/PM $10 / \mathrm{PM}_{2.5}-2$; flow rate: $77.59 \mathrm{~L} \mathrm{~min}^{-1}$ ). All the samplers were co-located with the online instruments on the roof $(\sim 20 \mathrm{~m})$ of the 4 th Teaching Building at Fudan University, Shanghai. The duration time of sampling was generally $24 \mathrm{~h}$. More samples with shorter duration time were collected during the heavy haze days. The filters before and after sampling were weighed using an analytical balance (Model: Sartorius 2004MP) with a reading precision $10 \mathrm{mg}$ after stabilizing in constant temperature $\left(20 \pm 1{ }^{\circ} \mathrm{C}\right)$ and humidity $(40 \pm 1 \%)$. All the procedures were strictly quality controlled to avoid the possible contamination of samples.

\subsection{Chemical analysis}

\subsubsection{Ion analysis}

One-fourth of each sample and blank filter was extracted ultrasonically by $10 \mathrm{~mL}$ deionized water $\left(18 \mathrm{M} \Omega \mathrm{cm}^{-1}\right)$. Eleven inorganic ions $\left(\mathrm{SO}_{4}^{2-}, \mathrm{NO}_{3}^{-}, \mathrm{F}^{-}, \mathrm{Cl}^{-}, \mathrm{NO}_{2}^{-}, \mathrm{PO}_{4}^{3-}\right.$, $\mathrm{NH}_{4}^{+}, \mathrm{Na}^{+}, \mathrm{K}^{+}, \mathrm{Ca}^{2+}, \mathrm{Mg}^{2+}$ ) and four organic acids (formic, acetic, oxalic, and methylsulfonic acid-MSA) were 
analyzed by Ion Chromatography (ICS 3000, Dionex), which consisted of a separation column (Dionex Ionpac AS 11), a guard column (Dionex Ionpac AG 11), a self-regenerating suppressed conductivity detector (Dionex Ionpac ED50) and a gradient pump (Dionex Ionpac GP50). The detail procedures were given elsewhere (Yuan et al., 2003).

\subsubsection{Element analysis}

Half of each sample and blank filter was digested at $170^{\circ} \mathrm{C}$ for $4 \mathrm{~h}$ in high-pressure Teflon digestion vessel with $3 \mathrm{~mL}$ concentrated $\mathrm{HNO}_{3}, 1 \mathrm{~mL}$ concentrated $\mathrm{HCl}$, and $1 \mathrm{~mL}$ concentrated HF. After cooling, the solutions were dried, and then diluted to $10 \mathrm{~mL}$ with distilled deionized water. Total 31 elements (Ag, $\mathrm{Al}, \mathrm{As}, \mathrm{Ba}, \mathrm{Br}, \mathrm{Ca}, \mathrm{Cd}, \mathrm{Ce}, \mathrm{Co}, \mathrm{Cr}, \mathrm{Cu}$, $\mathrm{Eu}, \mathrm{Fe}, \mathrm{Ge}, \mathrm{I}, \mathrm{K}, \mathrm{Mg}, \mathrm{Mn}, \mathrm{Mo}, \mathrm{Na}, \mathrm{Ni}, \mathrm{P}, \mathrm{Pb}, \mathrm{S}, \mathrm{Sb}, \mathrm{Sc}$, $\mathrm{Se}, \mathrm{Sr}, \mathrm{Ti}, \mathrm{V}$, and $\mathrm{Zn}$ ) were measured by using an inductively coupled plasma atomic emission spectroscopy (ICPOES; SPECTRO, Germany). The detailed analytical procedures were given elsewhere (Sun et al., 2004; Zhuang et al., 2001).

\subsubsection{Carbonaceous aerosol analysis}

Quartz filters were pre-heated at $500^{\circ}$ for $5 \mathrm{~h}$ before using and the samples were analyzed for OC/EC using DRI Model 2001 (Thermal/Optical Carbon Analyzer). The IMPROVE thermal/optical reflectance (TOR) protocol (Chow and Watson, 2002) was used for the carbon analysis. The eight fractions $\left(\mathrm{OC} 1, \mathrm{OC} 2, \mathrm{OC} 3, \mathrm{OC} 4\right.$ at $120,250,450$ and $550^{\circ} \mathrm{C}$, respectively in a helium atmosphere, EC1, EC2, EC 3 at 550, 700 and $800^{\circ} \mathrm{C}$, respectively, in the $98 \%$ helium $/ 2 \%$ oxygen atmosphere) and OPC (optically detected pyrolized carbon) were measured separately. The IMPROVE protocol defined $\mathrm{OC}$ as $\mathrm{OC} 1+\mathrm{OC} 2+\mathrm{OC} 3+\mathrm{OC} 4+\mathrm{OPC}$ and $\mathrm{EC}$ as $\mathrm{EC} 1$ $+\mathrm{EC} 2+\mathrm{EC} 3-\mathrm{OPC}$.

\subsection{Potential source contribution function}

In the study, the potential source contribution function (PSCF) was calculated to infer the potential source areas. Hopke et al. (1995) developed PSCF to identify the potential source regions giving rise to observed concentrations at a receptor site. In this model, air mass back trajectories are combined with the measured concentrations or identified source factor contribution to produce conditional probabilities over the region, where the region is subdivided into a number of grid cells. Three-days air mass back trajectories were calculated by running the NOAA Air Resource Lab (ARL) HYSPLIT model (R. Draxler and G. Rolph, HYSPLIT (HYbrid Single-Particle Lagrangian Integrated Trajectory) Model, 2003, http://www.arl.noaa.gov/ready/hysplit4.html), driven by the Global Data Assimilation System (GDAS) global reanalysis dataset. Backward trajectories were initiated every hour from $500 \mathrm{~m}$ above ground level over our measurement site. The total numbers $\left(n_{i, j}\right)$ of trajectory end- points (i.e. coordinates of the back trajectory for each hour before arriving at the receptor site) falling within grid cell $[i, j]$ during the study period are counted. Also, the number of those in the same grid cell with pollutant level higher than a set threshold was calculated as $m_{i, j}$. Then, the ratio between $n_{i, j}$ and $m_{i, j}$ is the PSCF value for this grid cell: $\mathrm{PSCF}_{i, j}=m_{i, j} / n_{i, j}$. To minimize the biased PSCF caused by the low $n_{i, j}$ values, $\mathrm{PSCF}_{i j}$ was weighted with $w_{i j}$ by setting at 0.05 for $n_{i, j} \leq 10,0.42$ for $10<n_{i, j} \leq 20$, and 0.70 for $20<n_{i, j} \leq 80$. Note that PSCF did not incorporate any emission input and could not resolve detailed small-scale features while it was an indication of the likelihood that a given region contributed to the receptor site.

\section{Results and discussion}

\subsection{Air pollution during the Chinese Spring Festival season}

One intensive atmospheric field campaign was carried out in Shanghai, an Eastern China megacity. The study period lasted from 15 January to 12 February in 2009, covering one of the most important Chinese traditional national holidays, the Chinese Spring Festival. The average concentrations of $\mathrm{PM}_{2.5}$ and $\mathrm{PM}_{10}$ during the study period were $61.5 \pm 47.3$ and $89.8 \pm 53.1 \mu \mathrm{g} \mathrm{m}^{-3}$, respectively. $\mathrm{PM}_{2.5}$ accounted for a dominant fraction of $68.5 \%$ in $\mathrm{PM}_{10}$, indicating that fine particle was the main source of aerosol in Shanghai. Figure 1 shows the times series of hourly $\mathrm{PM}_{2.5}, \mathrm{PM}_{10}$ concentrations, aerosol scattering $\left(\sigma_{\mathrm{sp}}\right)$ and absorbing coefficient $\left(\sigma_{\mathrm{ap}}\right)$, and single scattering albedo $(\omega)$ during the study period. Also, meteorological parameters are shown in the same figure, including hourly wind speed/direction, relative humidity, rainfall amount, and visibility.

There were several pollution episodes based on the particle concentration and visibility. The first pollution episode occurred from 16-18 January with average visibility of $4.1 \pm 2.2 \mathrm{~km}$. The average $\mathrm{PM}_{2.5}$ and $\mathrm{PM}_{10}$ concentration reached $85.4 \pm 33.2$ and $142.5 \pm 26.2 \mu \mathrm{g} \mathrm{m}^{-3}$, respectively. Correspondingly high aerosol scattering coefficient $\left(\sigma_{\mathrm{sp}}\right)$ also occurred with mean value of $297.2 \pm 189.8 \mathrm{M} \mathrm{m}^{-1}$ as shown in Fig. 1e.

As stated in the introduction section, the spring travel rush usually starts about 1-2 weeks before the Chinese Lunar New Year. During this period, most of the immigrant residents in Shanghai start traveling back to their birth places for a reunion with their families. Agents in companies, industries and government usually give their employees their holiday leave about a week before the holiday officially begins. Most people intend to travel during this period. As a result, the week before the Spring Festival is the busiest period for the transportation system, including road vehicles, railroads, and airlines. To meet the increasing demands on transportation resources, hundreds of thousands of temporary 


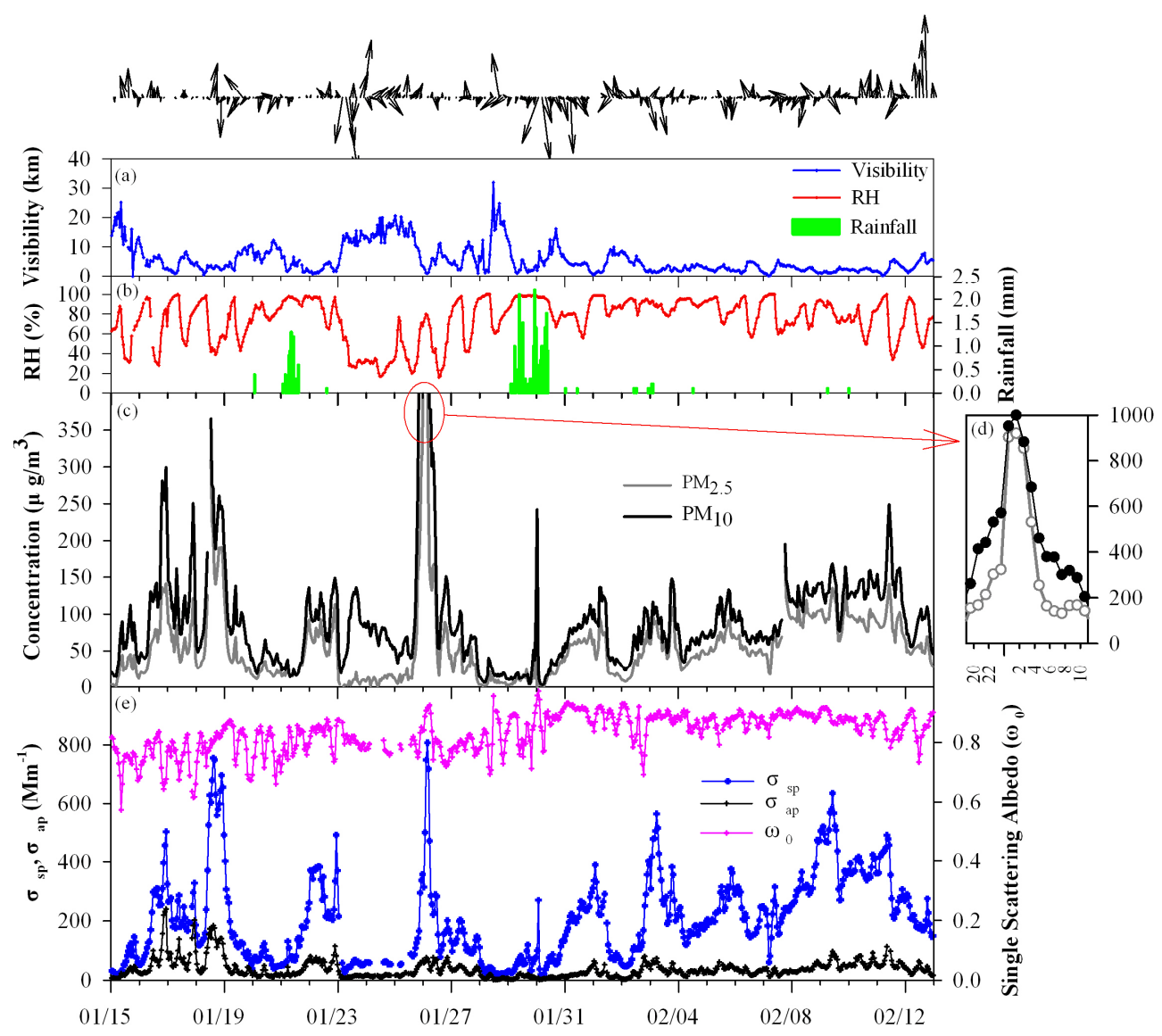

Fig. 1. Time series of meteorological conditions and various aerosol parameters with time resolution of $1 \mathrm{~h}$ from $15 \mathrm{January}$ to 12 February 2009 in Shanghai. (a) wind speed/direction and visibility (b) relatively humidity (RH) and rainfall (c) $\mathrm{PM}_{2.5}$ and $\mathrm{PM}_{10}$ mass concentration during the whole study period (d) $\mathrm{PM}_{2.5}$ and $\mathrm{PM}_{10}$ mass concentration on the Chinese Lunar New Year's Eve (25 January) and the Chinese Lunar New Year's Day (26 January) (e) aerosol scattering coefficient $\left(\sigma_{\mathrm{sp}}\right)$, absorption coefficient $\left(\sigma_{\mathrm{ap}}\right)$ and single scattering albedo $\left(\omega_{0}\right)$.

buses and trains are in operation. The average aerosol absorption coefficient $\left(\sigma_{\mathrm{ap}}\right)$ during this period in 2009 reached $89.2 \pm 56.7 \mathrm{M} \mathrm{m}^{-1}$, corresponding to the black carbon (BC) concentration of $8.5 \mu \mathrm{g} \mathrm{m}^{-3}$, which was the highest during the study period. This extremely high $\mathrm{BC}$ concentration corroborated the effect of spring travel rush on the air pollution as stated above. Consequently, the average single scattering albedo $(\omega)$, which was defined as the ratio of $\sigma_{\mathrm{sp}}$ to the total aerosol extinction coefficient $\left(\sigma_{\mathrm{sp}}+\sigma_{\mathrm{ap}}\right)$, reached the extremely low value of 0.76 , indicative of a large release of fresh combustion aerosol. Figure 2 shows the time series of hourly gaseous concentrations, including $\mathrm{NO}_{\mathrm{x}}\left(\mathrm{NO}+\mathrm{NO}_{2}\right)$, $\mathrm{CO}, \mathrm{SO}_{2}$, and $\mathrm{O}_{3}$. Of the major gases emitted from vehicle exhaust, $\mathrm{NO}_{\mathrm{x}}$ and $\mathrm{CO}$ evidenced the highest concentrations during this pollution episode. The average $\mathrm{NO}_{\mathrm{x}}$ and $\mathrm{CO}$ concentration reached remarkably high concentrations of 270 and $2572 \mu \mathrm{g} \mathrm{m}^{-3}$, respectively, indicating significantly increased vehicle emission. During this period, the relative humidity was at the moderate level of $\sim 70 \%$. Wind speeds maintained around $1.0 \mathrm{~m} \mathrm{~s}^{-1}$ and were occasionally stagnant
(Fig. 1). This typical stagnant synoptic meteorology favored the local atmospheric processing and accumulation of pollutants. As this pollution occurred before the Spring Festival, we denoted it as the "pre-holiday pollution episode".

In the following several days, the aerosol concentrations had obvious decreases, which was partly due to the increased wind speeds that favored the diffusion of pollutants and partly due to several precipitation events as shown in Fig. 1. Extremely high particle concentrations occurred on 25 and 26 January which were the exact dates of the Chinese Lunar New Year's Eve and Lunar New Year's Day. Particle concentrations began rising at 19:00 LST (Local Standard Time) on the 25th and remained at high levels for $\sim 16 \mathrm{~h}$ until 10:00 LST on 26 January 2009 (Fig. 1d). The hourly peaks climbed to over $900 \mu \mathrm{g} \mathrm{m}^{-3}$ of $\mathrm{PM}_{2.5}$ between 00:00 and 01:00 LST on the 26th, which was 10 to 20 times above the normal level. Correspondingly, the peak value of hourly $\sigma_{\mathrm{sp}}$ reached the extreme value of $807.2 \mathrm{M} \mathrm{m}^{-1}$. Additionally, the pollution gases $\mathrm{SO}_{2}$ and $\mathrm{NO}_{\mathrm{x}}$ reached very high levels of 438 and $286 \mu \mathrm{g} \mathrm{m}^{-3}$, respectively. The intensive and 


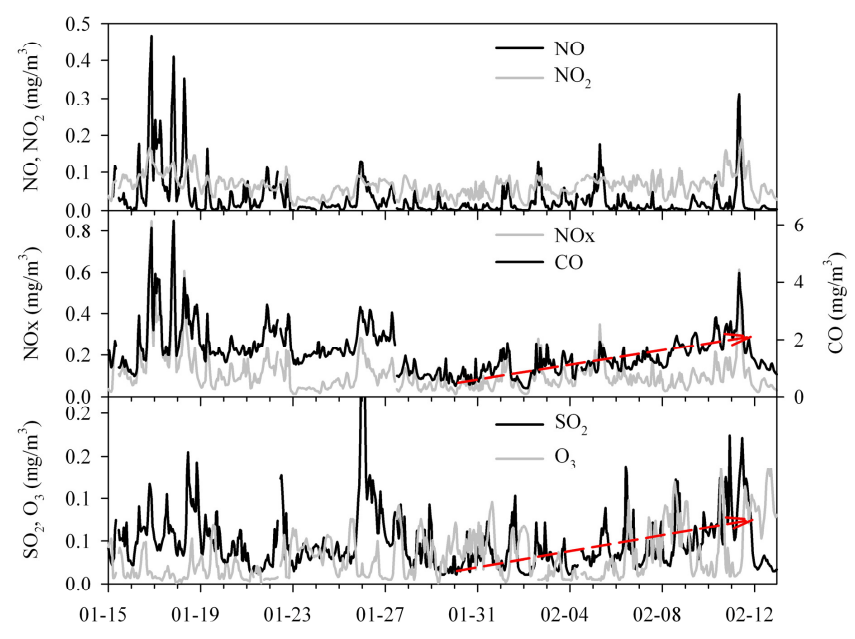

Fig. 2. Time series of hourly $\mathrm{NO}_{\mathrm{x}}\left(\mathrm{NO}+\mathrm{NO}_{2}\right), \mathrm{CO}, \mathrm{SO}_{2}$ and $\mathrm{O}_{3}$ concentrations. The dashed arrow lines denote the trends of $\mathrm{CO}$ and $\mathrm{SO}_{2}$ concentrations during the post-holiday pollution episode from 31 January to 11 February.

widespread exploding of fireworks was responsible for this burst of heavy pollution as all the residents were simultaneously celebrating the national holiday. The average visibility was $4.9 \mathrm{~km}$ and we denoted this period as the "holiday pollution episode". Afterwards, particle concentrations dropped considerably, probably due to the substantial decrease in exploding fireworks in addition to above normal precipitation on 29-31 January (total rainfall: $22.1 \mathrm{~mm}$ ).

After the seven-day national holiday, aerosol pollution started to rise on 31 January and persisted until 11 February. As visualized in Fig. 1, obviously increasing trends of PM concentrations and $\sigma_{\mathrm{sp}}$ were observed during this period on a daily basis. Correspondingly, some pollution gases, (i.e. $\mathrm{CO}, \mathrm{SO}_{2}$, and $\mathrm{NO}_{\mathrm{x}}$ ) also had similar temporal patterns, as shown in Fig. 2. We attributed this to another peak transport rush period after the national holiday, when people from other provinces and cities started returning to Shanghai for work and school. Daily increasing travel flows were reflected by the change of anthropogenic activities, such as increased usage of domestic and industrial electricity (e.g. $\mathrm{SO}_{2}$ ) and a greater demand on various transportation systems (e.g. $\mathrm{NO}_{\mathrm{x}}$ and $\mathrm{CO}$ ). The particle concentration was lower than the pre-holiday pollution with average $\mathrm{PM}_{2.5}$ and $\mathrm{PM}_{10}$ concentrations of 67.7 and $97.5 \mu \mathrm{g} \mathrm{m}^{-3}$, respectively. $\sigma_{\mathrm{sp}}$ in this period averaged $283.2 \pm 121.6 \mathrm{M} \mathrm{m}^{-1}$, close to the pre-holiday pollution episode. However, $\sigma_{\text {ap }}$ was much lower $\left(37.6 \pm 19.4 \mathrm{M} \mathrm{m}^{-1}\right)$ and almost $40 \%$ of the pre-holiday pollution episode. We explained that people had relatively flexible traveling schedules after the festival compared to the stringent schedule before the festival. Daily traffic emissions were probably not as concentrated, either, which explains the much lower $\sigma_{\mathrm{ap}}, \mathrm{NO}_{\mathrm{x}}\left(\mathrm{NO}, \mathrm{NO}_{2}\right)$, and CO levels. Visibility was lower during the whole study period than anytime during the year, with mean values of $2.96 \pm 1.77 \mathrm{~km}$. Relatively high humidity (Fig. 1a) was one of the important factors accounting for the low visibility. We denoted this pollution episode as the "post-holiday pollution episode".

\subsection{Source identification by PSCF}

We conducted PSCF analysis to explore the potential source regions of Shanghai's air pollution. The results, aiming at four air pollutant parameters (i.e. $\mathrm{SO}_{2}, \mathrm{NO}_{\mathrm{x}}, \mathrm{BC}$ and $\mathrm{PM}_{2.5}$ ), are shown in Fig. 3. Hourly measurement data from Shanghai with corresponding three days back trajectories at the altitude of $500 \mathrm{~m}$ during the whole study period were used as input for the PSCF model. The study revealed that there appeared to be fewer potential source regions for $\mathrm{SO}_{2}$ compared to the other pollutants (Fig. 3a). Since power plants were the major source for $\mathrm{SO}_{2}$ emission in YRD, we think that the higher PSCF values of $\mathrm{SO}_{2}$ were directly related to the distribution of power plants. Figure S2 shows the distribution of coal-fired power plants with the individual annual energy $(\mathrm{kWh})$ over the YRD region in 2009. It could be observed that higher PSCF values generally coincided with those areas where power plants with the larger energy capacity are located, e.g. southern Jiangsu province, major areas of Anhui province, and northern Jiangxi province.

The potential source regions of $\mathrm{NO}_{\mathrm{x}}$ and $\mathrm{BC}$ were more widespread than the source regions for $\mathrm{SO}_{2}$ (Fig. $3 \mathrm{~b}$ and c). $\mathrm{NO}_{\mathrm{x}}$ and $\mathrm{BC}$ were dominated by the line emission (e.g. vehicles) and area emission (e.g. industries and residential), which were more regionally distributed. Thus, Shanghai was most likely the recipient of $\mathrm{NO}_{\mathrm{x}}$ and $\mathrm{BC}$ from areas outside the city by means of regional transport. As shown in the figure, there is a high probability that $\mathrm{NO}_{\mathrm{x}}$ in Shanghai came from the southwest while $\mathrm{BC}$ had a high probability of drifting from the northwest. Compared to the relatively limited potential source regions of $\mathrm{SO}_{2}, \mathrm{NO}_{\mathrm{x}}$ and $\mathrm{BC}$ over the continent, $\mathrm{PM}_{2.5}$ of Shanghai evidently had a broad transport pathway from the northeast over the Eastern China Sea (Fig. 3d). We believe that the high PSCF values there were derived from the continental outflows from the North China Plain, e.g. Shandong province, Beijing, etc. Thus, particle pollution in Shanghai was partially caused by long-range transport from its upstream areas.

\subsection{Chemical signatures for pollution identification}

\subsubsection{Elemental concentration levels and source apportionment}

A total of 31 elements were measured and analyzed in this study, and their average concentrations with one standard deviation in $\mathrm{PM}_{2.5}$ and TSP are summarized in Table 1. Of all the elements, sulfur $(S)$ had the highest concentration with mean values of $4.12 \pm 3.26$ and $6.04 \pm 4.36 \mu \mathrm{g} \mathrm{m}^{-3}$ in $\mathrm{PM}_{2.5}$ and TSP, respectively. Sulfur mainly derived from the usage 
(a) PSCF: $\mathrm{SO}_{2}$

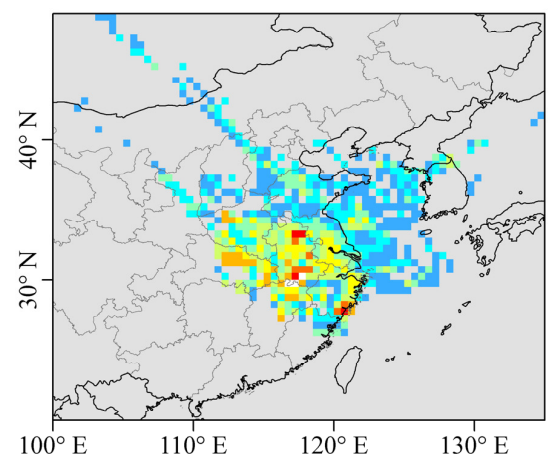

(c) PSCF: BC

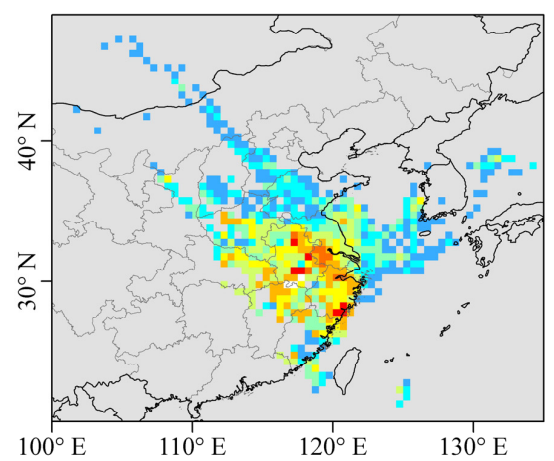

(b) PSCF: NOx

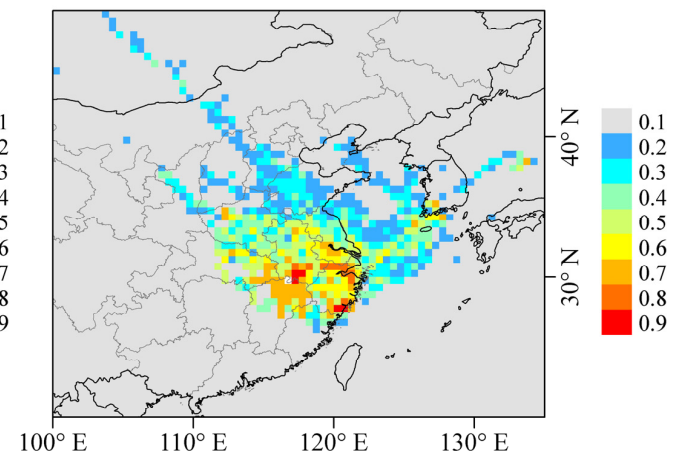

(d) PSCF: PM2.5

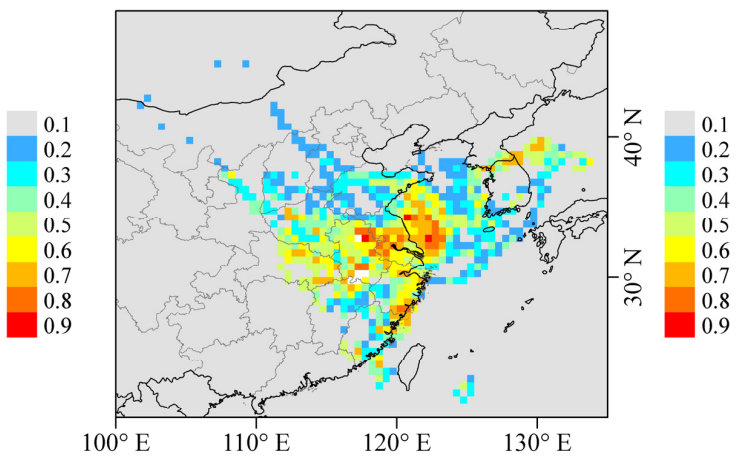

Fig. 3. Potential source contribution function (PSCF) maps for (a) $\mathrm{SO}_{2}$, (b) $\mathrm{NO}_{2}$, (c) $\mathrm{BC}$, and (d) $\mathrm{PM}_{2.5}$.

of coal and it indicated coal combustion was still a major component of air pollution in Shanghai. Al and Ca ranked the second and third among all the elements. Their concentrations in this study were a factor of 2-5 times lower than the previous results of 2004 and 2005 in Shanghai (Wang et al., 2006). One reason for this could be that emissions from construction activities were more effectively controlled due to the forthcoming 2010 Shanghai World Expo. Various measures were implemented to reduce construction and roadside dust pollution, including requirements on the covering or containment of idle soil, cement, and construction waste (UNEP, 2009). On the other hand, most of the construction sites were temporarily shut down due to the long Spring Festival vacation. By using the formula proposed by Malm et al. (1994), the mineral concentration could be calculated as $[$ Minerals $]=2.2[\mathrm{Al}]+2.49[\mathrm{Si}]+1.63[\mathrm{Ca}]+2.42[\mathrm{Fe}]+$ 1.94[Ti]. It accounted for about $12.0 \%$ and $27.7 \%$ to $\mathrm{PM}_{2.5}$ and TSP mass, respectively. This demonstrates that minerals contributed a minor part to the aerosol, especially in fine particles.

Enrichment degrees of elements could be assessed by using the enrichment factors (EF) analysis: $\mathrm{EF}=$ $\left(X / X_{\text {Ref }}\right)_{\text {aerosol }} /\left(X / X_{\text {Ref }}\right)_{\text {crust }}$, where $X$ was the element of interest and $X_{\text {Ref }}$ was the reference element with $\mathrm{Al}$ chosen in this study. Elements with EFs less than 10 were usually regarded to be primarily derived from natural sources, which included $\mathrm{Al}, \mathrm{Ca}, \mathrm{Fe}, \mathrm{Mg}, \mathrm{Na}, \mathrm{Sc}$, and $\mathrm{P}$ in this study. Elements with EFs in the range of 10-100 included Sr, Mn, K, $\mathrm{Ti}, \mathrm{V}, \mathrm{Ba}, \mathrm{Ni}, \mathrm{Cr}, \mathrm{Cu}$, and $\mathrm{Mo}$, suggesting that these elements were moderately contaminated. The remaining elements had EFs close to or elevated above 1000 . The average EFs of $\mathrm{Pb}$, $\mathrm{Zn}, \mathrm{Cd}$, As, Sb, S, and Se were 765, 936, 1258, 2431, 2793, 7552 , and 8888 , respectively, indicating that they were highly contaminated.

In order to further characterize the sources of elements, the principle component analysis (PCA) was applied by using the rotated component matrix. The results are shown in Table 2. Five factors were extracted from the whole dataset, which could explain $83.17 \%$ of the variance, suggesting most of the sources have been explained. The first factor (PC1) could explain $18.16 \%$ of the total variance and it indicates high loadings for $\mathrm{Al}, \mathrm{Ca}, \mathrm{Mg}, \mathrm{Na}, \mathrm{Ti}$ and moderate loading for $\mathrm{Fe}$. This factor obviously represents the natural source. The second factor ( $\mathrm{PC} 2)$, with a variation of $18.39 \%$, shows high loadings for $\mathrm{Co}, \mathrm{Cr}, \mathrm{Fe}, \mathrm{Mn}, \mathrm{Mo}$, and $\mathrm{Ni}$. We attribute this factor to vehicular emissions. Those trace metals are released into the atmosphere through the process of vehicular braking and the release of vehicular exhaust (Amato et al., 2009). The third factor (PC3) had a high loading for $\mathrm{Ba}, \mathrm{Cu}, \mathrm{K}$, and $\mathrm{Sr}$, and a moderate loading for 
Table 1. Average concentration of elements with one standard deviation $\left(\mu \mathrm{g} \mathrm{m}^{-3}\right)$ in $\mathrm{PM}_{2.5}$ and TSP.

\begin{tabular}{|c|c|c|c|c|}
\hline \multirow[b]{2}{*}{ Elements } & \multicolumn{2}{|c|}{$\mathrm{PM}_{2.5}$} & \multicolumn{2}{|c|}{ TSP } \\
\hline & Average & S.D. & Average & S.D. \\
\hline $\mathrm{Al}$ & 0.64 & 0.78 & 2.51 & 1.62 \\
\hline As & 0.019 & 0.007 & 0.018 & 0.009 \\
\hline $\mathrm{Ba}$ & 0.09 & 0.25 & 0.14 & 0.20 \\
\hline $\mathrm{Br}$ & BDL & BDL & 0.01 & 0.01 \\
\hline $\mathrm{Ca}$ & 0.72 & 0.78 & 3.39 & 1.63 \\
\hline $\mathrm{Cd}$ & $8.98 \times 10^{-4}$ & $5.57 \times 10^{-4}$ & $1.10 \times 10^{-3}$ & $9.74 \times 10^{-4}$ \\
\hline $\mathrm{Ce}$ & $1.70 \times 10^{-3}$ & $6.47 \times 10^{-3}$ & $1.71 \times 10^{-2}$ & $2.14 \times 10^{-2}$ \\
\hline $\mathrm{Co}$ & $4.15 \times 10^{-4}$ & $4.66 \times 10^{-4}$ & BDL & BDL \\
\hline $\mathrm{Cr}$ & 0.02 & 0.06 & 0.02 & 0.02 \\
\hline $\mathrm{Cu}$ & 0.04 & 0.02 & 0.07 & 0.09 \\
\hline $\mathrm{Eu}$ & $2.29 \times 10^{-4}$ & $6.71 \times 10^{-4}$ & $5.59 \times 10^{-3}$ & $8.88 \times 10^{-3}$ \\
\hline $\mathrm{Fe}$ & 0.56 & 0.50 & 1.93 & 1.07 \\
\hline $\mathrm{Ge}$ & 0.01 & 0.01 & BDL & BDL \\
\hline I & BDL & BDL & BDL & BDL \\
\hline $\mathrm{K}$ & 1.01 & 1.31 & 1.80 & 1.47 \\
\hline $\mathrm{Mg}$ & 0.26 & 0.27 & 0.81 & 0.62 \\
\hline $\mathrm{Mg}$ & 0.26 & 0.28 & 0.82 & 0.66 \\
\hline $\mathrm{Mn}$ & 0.04 & 0.04 & 0.07 & 0.04 \\
\hline Mo & $7.11 \times 10^{-4}$ & $5.61 \times 10^{-4}$ & $1.02 \times 10^{-3}$ & $1.09 \times 10^{-3}$ \\
\hline $\mathrm{Na}$ & 0.45 & 0.40 & 1.73 & 1.04 \\
\hline $\mathrm{Ni}$ & 0.01 & 0.02 & 0.01 & 0.01 \\
\hline $\mathrm{P}$ & 0.003 & 0.02 & 0.04 & 0.07 \\
\hline $\mathrm{Pb}$ & 0.06 & 0.04 & 0.11 & 0.21 \\
\hline S & 4.12 & 3.26 & 6.04 & 4.36 \\
\hline $\mathrm{Sb}$ & $3.06 \times 10^{-3}$ & $2.57 \times 10^{-3}$ & $4.46 \times 10^{-3}$ & $6.38 \times 10^{-3}$ \\
\hline $\mathrm{Sc}$ & $6.38 \times 10^{-5}$ & $6.44 \times 10^{-5}$ & $6.67 \times 10^{-5}$ & $1.26 \times 10^{-4}$ \\
\hline $\mathrm{Se}$ & $2.00 \times 10^{-3}$ & $1.60 \times 10^{-3}$ & $6.57 \times 10^{-4}$ & $9.84 \times 10^{-4}$ \\
\hline $\mathrm{Sr}$ & 0.02 & 0.03 & 0.06 & 0.17 \\
\hline $\mathrm{Ti}$ & 0.32 & 0.26 & 1.10 & 0.73 \\
\hline V & 0.01 & 0.01 & 0.01 & 0.01 \\
\hline $\mathrm{Zn}$ & 0.13 & 0.28 & 0.50 & 0.65 \\
\hline
\end{tabular}

S.D. denotes "standard deviation" and BDL denotes "below detection limit".

$\mathrm{Pb}$, which could explain $17.96 \%$ of the variance. At normal times, these metals derived from miscellaneous sources. As this study covered the most intense episodes of exploding fireworks, we conclude that these metals were probably built into fireworks during their production. Previous results from the Lantern Festival in Beijing also revealed that these metals increased substantially in the atmosphere when fireworks were exploded simultaneously en masse (Wang et al., 2007).

The fourth factor (PC4) showed high loadings for $\mathrm{Cd}, \mathrm{Pb}$, $\mathrm{Sb}$, and Se and could explain $15.89 \%$ of the variance. These elements probably came from industrial and metallurgical emissions. The major source of $\mathrm{Pb}$ in Shanghai in early years was from traffic emissions. Lead pollution dominated until leaded gasoline was phased out beginning in 1997. Now, coal combustion plays a major role in the release of emissions into the atmosphere (Chen et al., 2005; Tan et al., 2006; Zhang et al., 2009). This PCA analysis supports a final factor (PC5). It shows significant loadings for As, Ge, S, and Se, which evidently derived from coal burning. Se and $\mathrm{SO}_{4}^{2-}$ significantly correlates $(R=0.76)$ as shown in Fig. 6a. The extremely high enrichment of Se suggests that coal burning was a significant source of air pollution in Shanghai.
Table 2. Principle component analysis of the major elements.

\begin{tabular}{|c|c|c|c|c|c|}
\hline \multirow[b]{2}{*}{ Factor } & \multicolumn{5}{|c|}{ Rotated component matrix } \\
\hline & PC1 & PC2 & PC3 & PC4 & PC5 \\
\hline $\mathrm{Al}$ & 0.63 & -0.04 & 0.58 & 0.16 & -0.35 \\
\hline As & -0.09 & 0.10 & 0.33 & -0.02 & 0.85 \\
\hline $\mathrm{Ba}$ & 0.02 & -0.08 & 0.95 & 0.00 & 0.05 \\
\hline $\mathrm{Ca}$ & 0.90 & 0.04 & 0.22 & 0.02 & -0.30 \\
\hline $\mathrm{Cd}$ & 0.03 & -0.04 & 0.04 & 0.83 & 0.34 \\
\hline Co & 0.12 & 0.95 & -0.01 & 0.11 & 0.07 \\
\hline $\mathrm{Cr}$ & -0.16 & 0.95 & 0.05 & -0.21 & -0.07 \\
\hline $\mathrm{Cu}$ & 0.25 & 0.19 & 0.62 & 0.26 & 0.04 \\
\hline $\mathrm{Eu}$ & 0.21 & -0.09 & 0.48 & -0.39 & -0.35 \\
\hline $\mathrm{Fe}$ & 0.57 & 0.72 & 0.11 & 0.14 & -0.17 \\
\hline $\mathrm{Ge}$ & -0.02 & 0.12 & 0.04 & 0.34 & 0.85 \\
\hline $\mathrm{K}$ & 0.00 & 0.03 & 0.92 & 0.17 & 0.30 \\
\hline $\mathrm{Mg}$ & 0.74 & 0.00 & 0.56 & -0.12 & -0.03 \\
\hline $\mathrm{Mn}$ & 0.30 & 0.85 & -0.06 & 0.25 & 0.05 \\
\hline Mo & 0.16 & 0.65 & -0.13 & 0.59 & 0.20 \\
\hline $\mathrm{Na}$ & $\mathbf{0 . 8 7}$ & 0.01 & 0.05 & -0.18 & 0.15 \\
\hline $\mathrm{Ni}$ & -0.11 & 0.97 & -0.06 & -0.13 & 0.05 \\
\hline $\mathrm{Pb}$ & 0.06 & -0.10 & 0.56 & 0.73 & 0.26 \\
\hline S & -0.02 & -0.11 & 0.00 & 0.32 & 0.75 \\
\hline $\mathrm{Sb}$ & 0.21 & 0.14 & 0.08 & 0.83 & 0.09 \\
\hline $\mathrm{Sc}$ & 0.59 & 0.07 & 0.04 & 0.59 & -0.11 \\
\hline $\mathrm{Se}$ & -0.13 & -0.06 & 0.13 & 0.70 & 0.57 \\
\hline $\mathrm{Sr}$ & 0.12 & -0.09 & 0.95 & 0.00 & 0.10 \\
\hline $\mathrm{Ti}$ & 0.82 & 0.10 & 0.09 & 0.36 & -0.12 \\
\hline V & 0.58 & 0.22 & -0.17 & 0.27 & 0.28 \\
\hline $\begin{array}{l}\% \text { of } \\
\text { variance }\end{array}$ & 18.16 & 18.39 & 17.96 & 15.89 & 12.77 \\
\hline
\end{tabular}

\subsubsection{Pollution process analysis}

Since five major sources were extracted from the PCA analysis, it was necessary to show the time series of some typical elemental tracers in order to understand the atmospheric processing of different emission sources (Fig. 4). The time series of mineral source ( $\mathrm{PC} 1$ : $\mathrm{Al}, \mathrm{Ca}, \mathrm{Fe}, \mathrm{Na}$ ) showed high concentrations before the holiday. On the one hand, busy transportation before the holiday caused more suspension and resuspension of road dust. On the other hand, relatively low humidity (Fig. 1) did not favor the deposition of dust. It was noticed that highest peaks of mineral elements occurred from 23-25 January. The meteorological conditions in Fig. 1 indicate that RH had a sharp decrease from 23 January to around $20 \%$ in the next few days. In Fig. 1e, the $\mathrm{PM}_{2.5} / \mathrm{PM}_{10}$ ratio was observed to be the lowest ratio of 0.15 during the whole study period. Thus, this typical meteorological condition and characteristics of aerosol inferred that there was a cold front bringing floating dust, which was mainly composed of coarse particles rich in mineral elements. After the holiday, the levels of minerals stayed at low concentrations at most circumstances. Higher humidity may be one 


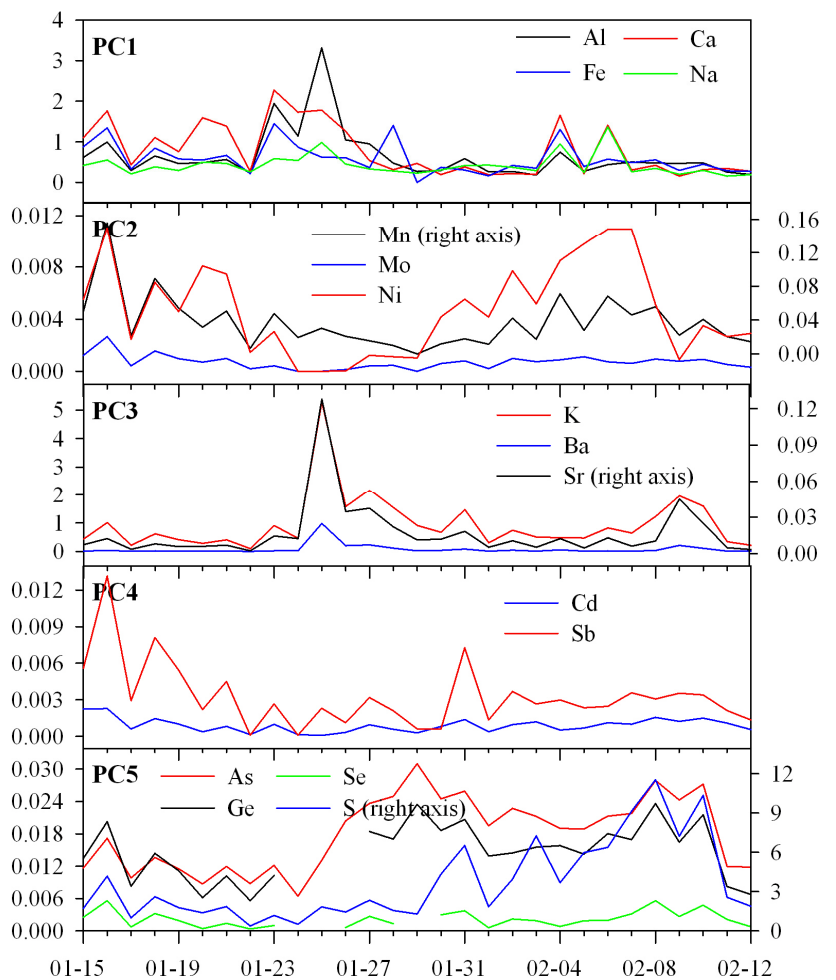

Fig. 4. Time series of typical elements from five major sources as determined by the Principle Component Analysis (PCA). All units are in $\mu \mathrm{g} \mathrm{m}^{-3}$.

of the causes for lowering the mineral aerosol. The traffic source (PC2: Mn, Mo, Ni) generally had a consistent temporal variation with the traffic related gases (e.g., $\mathrm{NO}_{\mathrm{x}}, \mathrm{CO}$ ) in Fig. 2, corroborating the effect of intensified traffic emission on aerosol chemical species during the two specific periods of the "spring travel rush" as discussed in Sect. 3.1. Tracers for fireworks (PC3: K, Ba, Sr) had small fluctuations during the study period except for the obvious enhancement on 25 January, which was the exact date of New Year's Eve. As for the industrial source ( $\mathrm{PC} 4: \mathrm{Cd}, \mathrm{Sb})$, higher concentrations occurred before the holiday and then it decreased during the holiday. After the holiday, it gradually increased again due to re-opening of factories. The temporal variations of the coal burning source (PC5: As, $\mathrm{Se}, \mathrm{Ge}, \mathrm{S}$ ) coincided well with that of $\mathrm{SO}_{2}$ (Fig. 2) and particulate $\mathrm{SO}_{4}^{2-}$ (Fig. 5). Higher elemental concentrations mainly occurred after the holiday and this was attributed to the higher demand for electricity when people were heading back home.

Figure 5 presented the time series of daily $\mathrm{SO}_{4}^{2-}, \mathrm{NO}_{3}^{-}$, $\mathrm{NH}_{4}^{+}$, and organic carbon (OC) concentrations in $\mathrm{PM}_{2.5}$ during the study period. During the pre-holiday pollution episode (16-18 January), the secondary inorganic species were at moderate levels. $\mathrm{SO}_{4}^{2-}, \mathrm{NO}_{3}^{-}$, and $\mathrm{NH}_{4}^{+}$averaged 5.3, 7.2 , and $5.5 \mu \mathrm{g} \mathrm{m}^{-3}$, respectively. The biggest contributor to aerosol was OC, which averaged $13.7 \mu \mathrm{g} \mathrm{m}^{-3}$ and showed

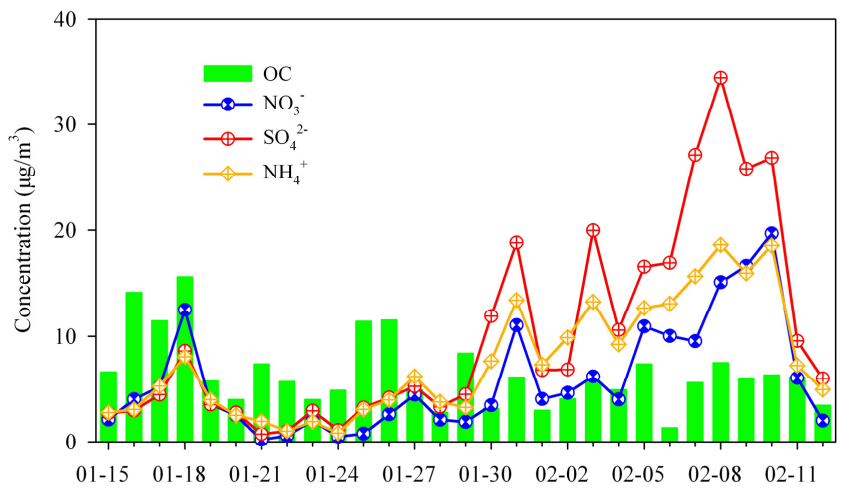

Fig. 5. Time series of daily $\mathrm{OC}, \mathrm{NO}_{3}^{-}, \mathrm{SO}_{4}^{2-}$, and $\mathrm{NH}_{4}^{+}$concentrations $\left(\mu \mathrm{g} \mathrm{m}^{-3}\right)$ during the study period.

the highest levels during the whole period. If we applied an $\mathrm{OM} / \mathrm{OC}$ ratio of 2.0 to estimate the mass of organic matter (OM) (Turpin and Lim, 2001), the average mass contribution of $\mathrm{OM}$ to $\mathrm{PM}_{2.5}$ could be as high as $44.6 \%$. As discussed in Sect. 3.1, we have mainly attributed this pollution episode to increased vehicle emissions. Figure $6 \mathrm{~b}$ shows the linear correlation between $\mathrm{OC}$ and $\mathrm{CO}$, and their significant correlation ( $R=0.71$ ), corroborating the impact of vehicle emissions on the first pollution episode.

In the following days from 19-24 January, all the chemical species stayed at relatively low levels. As discussed above, favorable meteorological conditions, e.g. higher wind speed and more precipitation, played an important role. During the holiday pollution episode (25-26 January), OC concentration had doubled compared to the previous days (19-24 January), with the average concentration of $11.5 \mu \mathrm{g} \mathrm{m}^{-3}$. At the same time, the secondary inorganic species remained low with 3.7, 1.7 , and $3.5 \mu \mathrm{g} \mathrm{m}^{-3}$ for $\mathrm{SO}_{4}^{2-}, \mathrm{NO}_{3}^{-}$, and $\mathrm{NH}_{4}^{+}$, respectively. We speculate that the remaining part of aerosol derived from the explosion of fireworks, which have been identified as oxidated metal that was added to fireworks during production.

During the post-holiday episode (31 January-10 February), organic aerosol was at a moderate level while the secondary inorganic species reached the highest levels during the study period. $\mathrm{SO}_{4}^{2-}, \mathrm{NO}_{3}^{-}$, and $\mathrm{NH}_{4}^{+}$averaged 19.2 , 10.2 , and $13.4 \mu \mathrm{g} \mathrm{m}^{-3}$, respectively. The sum of these three species accounted for a dominant fraction of $74 \%$ in $\mathrm{PM}_{2.5}$. Consistent with the temporal variation of aerosol concentrations, aerosol scattering coefficient and pollutant gases (Figs. 1 and 2), $\mathrm{SO}_{4}^{2-}, \mathrm{NO}_{3}^{-}$, and $\mathrm{NH}_{4}^{+}$also exhibited an upward trend during the post-holiday episode. This day-today pattern reflected that vehicular and industrial emissions had gradually increased probably due to growth of human flows from regions outside Shanghai and the re-opening of most industries. It was noted that the $\mathrm{NH}_{4}^{+}$concentration during the post-holiday pollution episode was 3-4 times higher than normal. The increased $\mathrm{NH}_{4}^{+}$was attributed to anthropogenic activities such as vehicular exhaust, human 

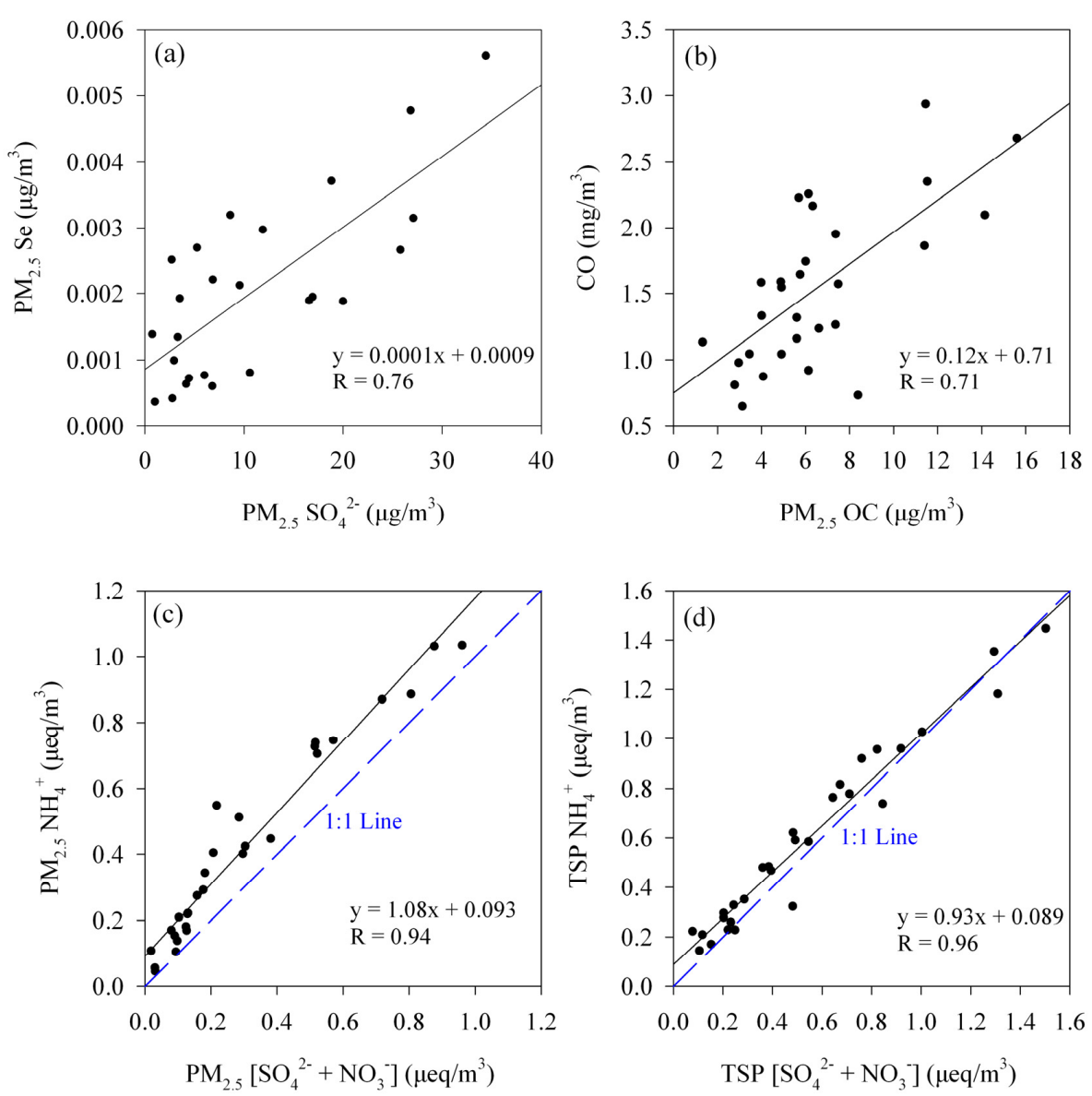

Fig. 6. The linear correlation between (a) $\mathrm{Se}$ and $\mathrm{SO}_{4}^{2-}$ in $\mathrm{PM}_{2.5}$ (b) $\mathrm{CO}$ and $\mathrm{PM}_{2.5} \mathrm{OC}$ (c) the equivalent $\mathrm{NH}_{4}^{+}$concentration and the sum of equivalent $\mathrm{SO}_{4}^{2-}$ and $\mathrm{NO}_{3}^{-}$concentration in $\mathrm{PM}_{2.5}$ and (d) TSP. The dashed blue line denotes the 1:1 line.

excrement, burning of agriculture straw, etc. $\mathrm{NH}_{4}^{+}$was a major alkaline component for neutralizing acids. As shown in Fig. $6 \mathrm{c}$ and d, the equivalent $\mathrm{NH}_{4}^{+}$concentration had a perfect linear correlation $(R>0.90)$ with the sum of $\mathrm{SO}_{4}^{2-}$ and $\mathrm{NO}_{3}^{-}$equivalent concentrations in both $\mathrm{PM}_{2.5}$ and TSP. And the slopes between $\mathrm{NH}_{4}^{+}$versus $\left[\mathrm{SO}_{4}^{2-}+\mathrm{NO}_{3}^{-}\right]$were close or slightly higher than 1.0 , indicating complete neutralization. Thus, the enhancement of ammonium was the major cause for the increase of sulfate and nitrate.

Atmospheric $\mathrm{NH}_{3}$ levels are high in the most polluted areas in China such as NCP (North China Plain), and YRD (Yangtze River delta). The $90 \%$ increase of $\mathrm{NH}_{3}$ emissions during 1990-2005 resulted in $\sim 50-60 \%$ increases of $\mathrm{NO}_{3}^{-}$ and $\mathrm{SO}_{4}^{2-}$ aerosol concentrations (Wang et al., 2011). It was suggested that the most effective pathway to mitigate air pollution is to adopt a multi-pollutant strategy to control $\mathrm{NH}_{3}$ emissions in parallel with current $\mathrm{SO}_{2}$ and $\mathrm{NO}_{\mathrm{x}}$ controls in China.

\subsection{Factors affecting the visibility impairment}

\subsubsection{Role of ambient water vapor}

Figure 7a shows the scatter plot between hourly visibility and $\mathrm{PM}_{2.5}$ concentration grouped by the corresponding relative humidity (RH). The data with precipitation events and intense events of exploding fireworks was excluded to avoid the statistical analysis of extreme values. Generally, the two parameters presented a negative relationship but it was nonlinear. If we use a threshold of visibility of $10 \mathrm{~km}$ to distinguish between haze and non-haze weather, it could be observed visually that the non-haze events (i.e., visibility $\geq 10 \mathrm{~km}$ ) were usually accompanied by $\mathrm{PM}_{2.5}$ concentrations lower than $65 \mu \mathrm{g} \mathrm{m}^{-3}$. It was also noted that there was relatively low humidity during non-haze episodes while for the haze events (i.e., visibility $<10 \mathrm{~km}) \mathrm{PM}_{2.5}$ concentrations fluctuated dramatically. The relative humidity $(\sim 80 \%)$ was much higher during the haze events than the non-haze events. As visualized in this figure, for a fixed visibility, $\mathrm{PM}_{2.5}$ concentration with higher RH was lower than that with lower RH. In other words, at higher RH the atmospheric visibility should 

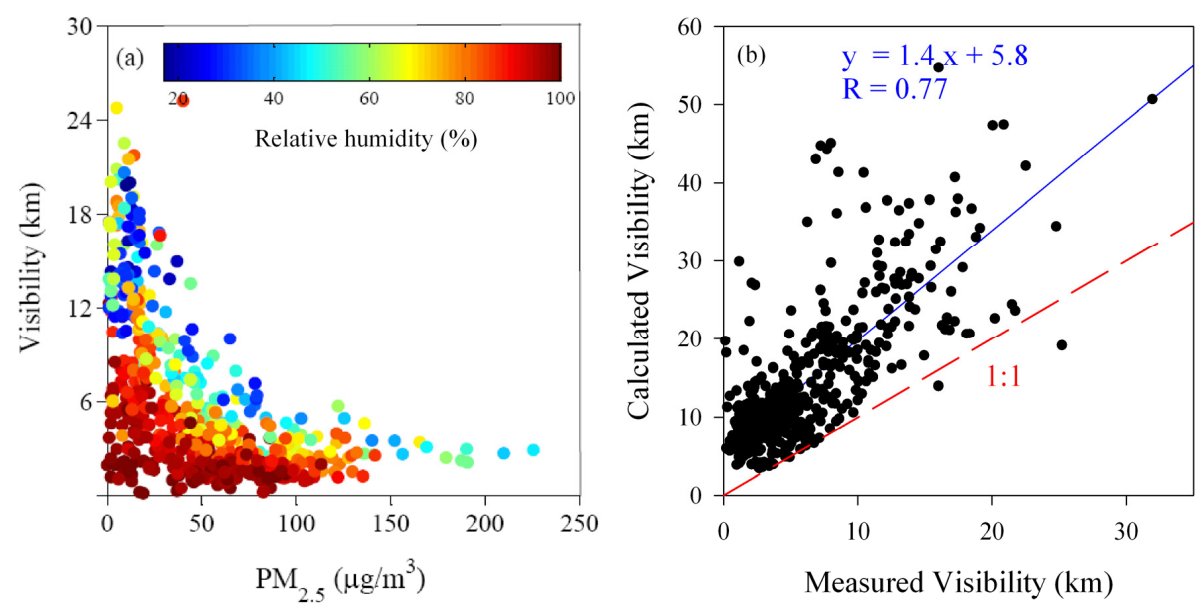

Fig. 7. (a) Scatter plot between hourly visibility and $\mathrm{PM}_{2.5}$ concentration grouped by the corresponding relatively humidity (b) linear relationship between the measured and calculated visibility, the regression equation and 1:1 line are also shown in the figure.

be more easily impaired by aerosol. This phenomenon was related to the dependence of aerosol scattering efficiency on the ambient water content. Major aerosol components, such as sulfate, nitrate, and ammonium were highly hygroscopic. When RH increased, the aerosol scattering efficiency would exponentially increase (Day and Malm, 2001).

To quantitatively investigate the impact of ambient water vapor on the atmospheric visibility, we compared the visibility measured by a visibility ambient light sensor and the calculated visibility estimated from the aerosol scattering and absorption coefficient. Visibility had an inverse relationship with total extinction coefficient according to the Koschmieder formula $L_{\mathrm{V}}=3.912 / \sigma_{\text {ext }}$ (Eq. 1), where $L_{\mathrm{V}}$ was the visibility and the total extinction coefficient $\sigma_{\text {ext }}$ was due to scattering and absorption by particles and gases, $\sigma_{\mathrm{ext}}=\sigma_{\mathrm{sp}}+\sigma_{\mathrm{ap}}+\sigma_{\mathrm{sg}}+\sigma_{\mathrm{ag}}+\sigma_{\mathrm{sw}}$ (Eq. 2). Scattering $\left(\sigma_{\mathrm{sp}}\right)$ and absorption coefficient $\left(\sigma_{\mathrm{ap}}\right)$ by particles were measured by nephelometer and aethalometer, respectively. Absorption of visible light by gases $\left(\sigma_{\mathrm{ag}}\right)$ was considered to be essentially due to $\mathrm{NO}_{2}$ and it could be estimated using the formula $\sigma_{\mathrm{ag}}=0.33 \times\left[\mathrm{NO}_{2}\right]$ (Groblicki et al., 1981). Here, $\mathrm{NO}_{2}$ was in units of $\times 10^{-9} \mathrm{~V} / \mathrm{V}$. Rayleigh scattering coefficient $\left(\sigma_{\mathrm{sg}}\right)$ was assumed to be a constant of $0.013 \mathrm{~km}^{-1}$ at sea level (Chan et al., 1999; Peundorf, 1957). And $\sigma_{\mathrm{sw}}$ was the scattering coefficient of light due to moisture in the air, which was not measured in this study. We calculated the extinction coefficient without $b_{\mathrm{sw}}$ and then converted into visibility using Eq. (1). The calculated visibility was denoted as Vis $\mathrm{sal}_{\mathrm{cal}}$ and the measured visibility was denoted as Vis mea. Figure $7 \mathrm{~b}$ shows the scatter plot between $\mathrm{Vis}_{\mathrm{cal}}$ and Vis mea. The two parameters were closely correlated with a correlation coefficient of 0.77 . However, the measured and calculated visibility had great discrepancy as indicated by the regression slope of $\mathrm{Vis}_{\mathrm{cal}} / \mathrm{Vis}_{\text {mea }}=1.4$. This indicated that there must be other parameters contributing to the total extinction. As we calculated the visibility without adding $b_{\mathrm{sw}}$, we believed that this discrepancy between the measured and calculated values should be due to the ambient water vapor. $b_{\mathrm{sw}}$ could be neglected when relatively humidity (RH) was lower than $70 \%$ (Cass, 1979; Chan et al., 1999), while in this study the average relative humidity during the whole study period reached over $75 \%$ and it exceeded $80 \%$ during the post-holiday pollution episode as inferred in Sect. 3.1.

Shanghai is a coastal city and its climate is humid with over $70 \% \mathrm{RH}$ all year around (Wang et al., 2006). Thus, it was not proper to exclude $b_{\mathrm{sw}}$ out of the calculation of the total extinction and this could explain the overestimated visibility. Based on the regression slope in Fig. 7b and Eq. (1), we could estimate that the contribution of water vapor to the visibility impairment was about $50 \%$. On the one hand, the high humidity caused considerable light extinction due to itself. On the other hand, the high humidity could make some hygroscopic components (e.g. sulfate ammonium, nitrate ammonium) become larger and more efficiently scatter light. Previous studies showed that the contribution of water content to the total sunlight scattering could be over $40 \%$ at one background site in the Yangtze River Delta region (Xu et al., 2002), and also around $40 \%$ at one site in the Pearl River Delta region with $80 \%$ RH (Cheng et al., 2008a). Even in Beijing, the contribution of water vapor could reache $25 \%$ in summer (Zhang et al., 2010). In this study, the role of ambient water vapor on light extinction was higher than the above studies, which could be due to the higher RH in this study.

\subsubsection{Aerosol optical properties apportioned to chemical composition}

In this section, the contribution of different chemical composition to the aerosol extinction was quantified. Aerosol was categorized into six groups, i.e., sulfate ammonium, nitrate ammonium, organic aerosol, elemental carbon, dust, and sea salt. As shown in Fig. 6, the equivalent ratio of $\mathrm{NH}_{4}^{+}$versus 


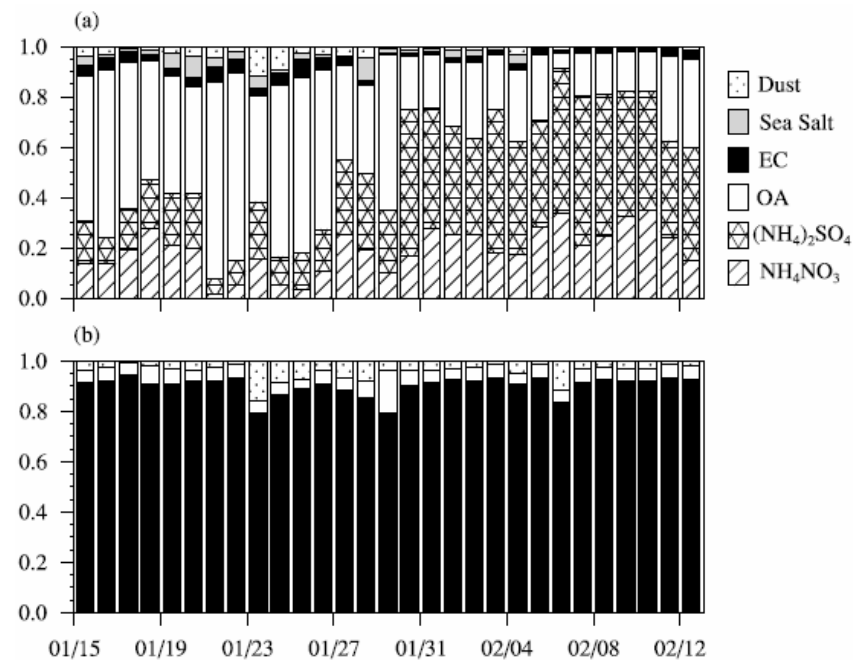

Fig. 8. Time series of fractional contribution of major aerosol components (i.e., dust, sea salt, elemental carbon (EC), organic aerosol (OA), $\left(\mathrm{NH}_{4}\right)_{2} \mathrm{SO}_{4}$ and $\left.\mathrm{NH}_{4} \mathrm{NO}_{3}\right)$ to (a) the aerosol scattering coefficient and (b) the aerosol absorption coefficient, respectively.

the sum of $\mathrm{SO}_{4}^{2-}$ and $\mathrm{NO}_{3}^{-}$was close to 1.00 . Thus, the concentration of sulfate ammonium and nitrate ammonium could be estimated using the formula: $m\left[\left(\mathrm{NH}_{4}\right)_{2} \mathrm{SO}_{4}\right]=m\left[\mathrm{SO}_{4}^{2-}\right]$ $\times(1+18 \times 2 / 96),\left[\mathrm{NH}_{4} \mathrm{NO}_{3}\right]=m\left[\mathrm{NO}_{3}^{-}\right] \times(1+18 / 62)$. Of which $m\left[\mathrm{SO}_{4}^{2-}\right]$ and $m\left[\mathrm{NO}_{3}^{-}\right]$represented the mass concentration of $\mathrm{SO}_{4}^{2-}$ and $\mathrm{NO}_{3}^{-}$, and 18,96 , and 62 represented the molecular weight of $\mathrm{NH}_{4}^{+}, \mathrm{SO}_{4}^{2-}$, and $\mathrm{NO}_{3}^{-}$, respectively. Organic aerosol (OA) was estimated by applying an OM/OC ratio of 2.0 (Turpin and Lim, 2001). Estimation of sea salts assumed all the measured $\mathrm{Na}^{+}$was derived from the marine source, and the sea salts were estimated using [sea salt] $=\left[\mathrm{Na}^{+}\right]+\left[\mathrm{Na}^{+}\right] \times 2.645$. Here, 2.645 was the seawater mass ratio of the other ions $\left(\mathrm{Cl}^{-}, \mathrm{SO}_{4}^{2-}, \mathrm{Ca}^{2+}, \mathrm{Mg}^{2+}, \mathrm{K}^{+}\right)$ to $\mathrm{Na}^{+}$. The estimation of dust aerosol had been stated in Sect. 3.3.1. As no scattering and absorption efficiencies of chemical species in the Yangtze River Delta region were reported yet, we adopted these parameters that were investigated in the Pearl River Delta region (Table 3 in Cheng et al., 2008b).

Figure 8 shows the fractional contributions of major chemical composition to the aerosol scattering and absorption during the whole study period. It was found that the whole study period could be divided into two periods. From 1526 January, the aerosol scattering was dominated by the organic aerosol and its average contribution to the aerosol scattering reached $59 \%$ during this period. Except for the pre-holiday pollution episode when traffic emissions dominated, the other low PM periods were also dominated by the organic aerosol. This indicated that organic aerosol had served as an important background aerosol component in Shanghai. Since 27 January, the contribution from inorganic components to the aerosol scattering started to overwhelm

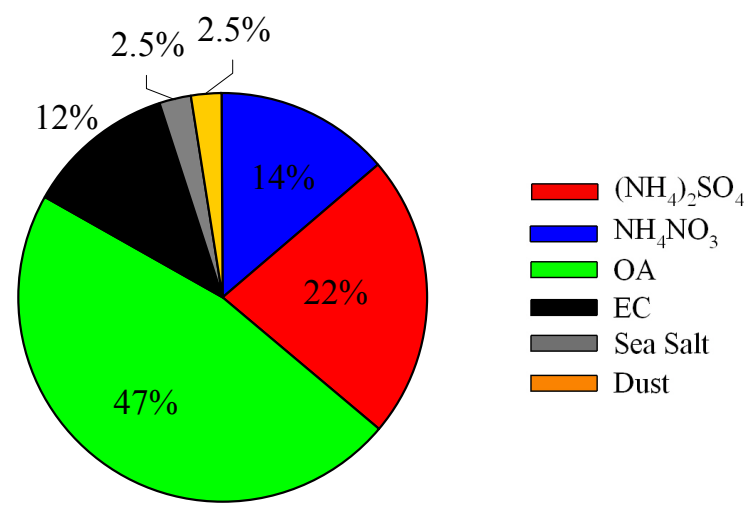

Fig. 9. Fractional contribution of major aerosol components (i.e., $\mathrm{SO}_{4}^{2-}, \mathrm{NO}_{3}^{-}, \mathrm{NH}_{4}^{+}$, organic aerosol (OA), elemental carbon (EC), sea salt and dust) to the total aerosol extinction.

that of organic aerosol. The average contribution of sulfate and nitrate reached about $69 \%$, while that of OA decreased to $26 \%$. Compared to the secondary inorganic and organic components, the contribution of EC, sea salt and dust to the aerosol scattering was much smaller, which, when totaled, contributed about $7 \%$. Figure $8 \mathrm{~b}$ shows the fractional contributions of major chemical species to the aerosol absorption. Elemental carbon evidently dominated the absorption during the whole study, accounting for an average of over $90 \%$ due to the fact that EC had the strongest absorption efficiency. Although organic aerosol and dust also had absorptive effect, their magnitudes were significantly lower than that of EC.

Finally, we summarized the contribution of major chemical species to the total aerosol extinction (scattering + absorbing) in Fig. 9. Organic aerosol had the largest contribution at $47 \%$, whose source we determined was likely derived from vehicle emissions. The next two biggest contributors were sulfate ammonium and nitrate ammonium, which contributed an average of $22 \%$ and $14 \%$, respectively. Although EC only comprised about $2 \sim 5 \%$ of the aerosol mass concentration, its contribution to the aerosol extinction was as high as $12 \%$, due to its highest extinction efficiency. From the results above, we could find that traffic-related species (i.e., OA, nitrate and EC) all had significant radiative effects, which highlights the importance of controlling vehicle numbers and emissions on the air pollution in mega-cities of China.

Although automobile emissions have been greatly reduced by using advanced technology, the dramatic increase in vehicles numbers and driving miles has offset much of the emission control progress. Controlling the number of vehicles on the road is at least as important as controlling vehicle emissions. As the number of private cars goes up very quickly in the mega-cities in China, restriction of private cars should be an effective measure for the short-term. The traffic congestion has been exacerbated in recent years by the dramatic increase in vehicle numbers, which grew much faster than the 
road infrastructure (Lin, 2003). On the one hand, the measures to solve the traffic congestion should not only include revising traffic-management schemes, such as building and improving public transport, promoting bike use and walking, but also by more efficient land-use patterns, the aim being to decrease or eliminate the need to drive to and from work, school, and shopping outlets. On the other hand, the social inequities derived from automobile usage should be taken into consideration in the effort to restrict the increasing private ownership of cars. The costs of driving a car affect not only the individual, but society and come in the forms of increased air pollution, increased health issues and a burdened public infrastructure. However, while these costs are now imposed on the whole society, they should be assumed by individual car owners. Environmental awareness of curbing traffic pollution should be raised amongst the general public.

\section{Conclusions}

We initiated an intensive atmospheric campaign during the Chinese Spring Festival peak transportation season of 2009 in Shanghai, a Chinese megacity. Three pollution episodes dominated by different emission sources were identified prior to, during, and after the holiday, respectively. The "spring travel rush" before the holiday caused significantly increased vehicle emissions as a vast number of immigrant residents in Shanghai were traveling back to their hometown. Black carbon reached the highest of $8.5 \mu \mathrm{g} \mathrm{m}^{-3}$ during the whole study period with extremely low single scattering albedo of 0.76 , indicating strong fresh combustion. Organic aerosol dominated with contributions of $45 \%$ and $60 \%$ to $\mathrm{PM}_{2.5}$ mass and the total aerosol scattering, respectively. On the New Year's Eve and Day, aerosol mass, scattering coefficient, and pollution gases (e.g. $\mathrm{SO}_{2}, \mathrm{NO}_{\mathrm{x}}$ ) peaked due to intense burning of fireworks during the celebration of the Chinese New Year. After the holiday, gradually increasing emissions due to "spring travel rush" resulted in increases of various pollutants. $\mathrm{SO}_{4}^{2-}, \mathrm{NO}_{3}^{-}$, and $\mathrm{NH}_{4}^{+}$averaged 19.2, 10.2, and $13.4 \mu \mathrm{g} \mathrm{m}^{-3}$, respectively, totaling a dominant fraction of $74 \%$ in $\mathrm{PM}_{2.5}$. Principle component analysis on 31 elements apportioned five major sources, i.e. natural sources, vehicular emissions, burning of fireworks, industrial and metallurgical emissions, and coal burning. Time series of typical trace elements illustrated well the variation of different emission sources. Correlation between $\mathrm{PM}_{2.5}$ and visibility indicated higher relative humidity had tremendous acceleration on the visibility impairment. Comparison between the measured and calculated visibility estimated that the effect of ambient water vapor contributed as high as $50 \%$ to the total light extinction. Among the total causes of aerosol extinction, organic aerosol contributed most at $47 \%$, followed by sulfate ammonium and nitrate ammonium with shares of $22 \%$ and $14 \%$, respectively. Although black carbon only comprised about $2-5 \%$ of the aerosol mass, its contribution to the aerosol extinction was as high as $12 \%$. Overall, we found that traffic-related species (i.e. organics, nitrate and black carbon) all had significant radiative effects, which highlight the importance of controlling vehicle numbers and emissions on the air pollution in mega-cities of China.

\section{Supplementary material related to this article is available online at: http://www.atmos-chem-phys.net/12/ 11631/2012/acp-12-11631-2012-supplement.pdf.}

Acknowledgements. This work was supported by National Natural Science Foundation of China (Grant Nos. 41128005 (fund for collaboration with overseas scholars), 21277030, 20977017), Shanghai environmental protection science developing funding (No. 2011-55), and the great international collaboration project of MOST, China (2010DFA92230). We greatly appreciate Tisha Thomas help improve the language of this paper.

Edited by: A. B. Guenther

\section{References}

Amato, F., Pandolfi, M., Viana, M., Querol, X., Alastuey, A., and Moreno, T.: Spatial and chemical patterns of $\mathrm{PM}_{10}$ in road dust deposited in urban environment, Atmos. Environ., 43, 16501659, 2009.

Anderson, T. L. and Ogren, J. A.: Determining aerosol radiative properties using the TSI 3563 integrating nephelometer, Aerosol Sci. Tech., 29, 57-69, 1998.

Arnott, W. P., Hamasha, K., Moosmuller, H., Sheridan, P. J., and Ogren, J. A.: Towards aerosol light-absorption measurements with a 7-wavelength Aethalometer: Evaluation with a photoacoustic instrument and 3-wavelength nephelometer, Aerosol Sci. Tech., 39, 17-29, 2005.

BBC: China's holiday rush begins early, http://news.bbc.co.uk/2/hi/ asia-pacific/7813267.stm, last access: January 2009.

Cass, G. R.: On the relationship between sulfate air quality and visibility with examples in los angeles, Atmos. Environ., 13, 10691084, 1979.

Chan, C. K. and Yao, X.: Air pollution in mega cities in China, Atmos. Environ., 42, 1-42, 2008.

Chan, Y. C., Simpson, R. W., McTainsh, G. H., Vowles, P. D., Cohen, D. D., and Bailey, G. M.: Source apportionment of visibility degradation problems in Brisbane (Australia) using the multiple linear regression techniques, Atmos. Environ., 33, 3237-3250, 1999.

Che, W. W., Zheng, J. Y., Wang, S. S., Zhong, L. J., and Lau, A. I.: Assessment of motor vehicle emission control policies using Model-3/CMAQ model for the Pearl River Delta region, China, Atmos. Environ., 45, 1740-1751, 2011.

Chen, J. M., Tan, M. G., Li, Y. L., Zhang, Y. M., Lu, W. W., Tong, Y. P., Zhang, G. L., and Li, Y.: A lead isotope record of shanghai atmospheric lead emissions in total suspended particles during the period of phasing out of leaded gasoline, Atmos. Environ., 39, 1245-1253, 2005. 
Cheng, Y. F., Wiedensohler, A., Eichler, H., Heintzenberg, J., Tesche, M., Ansmann, A., Wendisch, M., Su, H., Althausen, D., Herrmann, H., Gnauk, T., Bruggemann, E., Hu, M., and Zhang, Y. H.: Relative humidity dependence of aerosol optical properties and direct radiative forcing in the surface boundary layer at Xinken in Pearl River Delta of China: An observation based numerical study, Atmos. Environ., 42, 6373-6397, 2008a.

Cheng, Y. F., Wiedensohler, A., Eichler, H., Su, H., Gnauk, T., Brueggemann, E., Herrmann, H., Heintzenberg, J., Slanina, J., Tuch, T., Hu, M., and Zhang, Y. H.: Aerosol optical properties and related chemical apportionment at Xinken in Pearl River Delta of China, Atmos. Environ., 42, 6351-6372, 2008b.

Chow, J. C. and Watson, J. G.: $\mathrm{PM}_{2.5}$ carbonate concentrations at regionally representative Interagency Monitoring of Protected Visual Environment sites, J. Geophys. Res., 107, 8344, doi:10.1029/2001JD000574, 2002.

Day, D. E. and Malm, W. C.: Aerosol light scattering measurements as a function of relative humidity: a comparison between measurements made at three different sites, Atmos. Environ., 35, 5169-5176, 2001.

Fu, Q. Y., Zhuang, G. S., Wang, J., Xu, C., Huang, K., Li, J., Hou, B., Lu, T., and Streets, D. G.: Mechanism of formation of the heaviest pollution episode ever recorded in the Yangtze River Delta, China, Atmos. Environ., 42, 2023-2036, 2008.

Groblicki, P. J., Wolff, G. T., and Countess, R. J.: VisibilityReducing Species in the Denver Brown Cloud. 1. Relationships between Extinction and Chemical-Composition, Atmos. Environ., 15, 2473-2484, 1981.

He, Q. S., Li, C. C., Geng, F. H., Yang, H. Q., Li, P. R., Li, T. T., Liu, D. W., and Pei, Z.: Aerosol optical properties retrieved from sunphotometer over Shanghai, China, J. Geophys. Res.-Atmos., 117, D16204, doi:10.1029/2011JD017220, 2012.

Hopke, P. K., Barrie, L. A., Li, S. M., Cheng, M. D., Li, C., and Xie, Y.: Possible sources and preferred pathways for biogenic and non-sea-salt sulfur for the high Arctic, J. Geophys. Res., 100, 16595-16603, doi:10.1029/95JD01712, 1995.

Huang, K., Zhuang, G., Lin, Y., Fu, J. S., Wang, Q., Liu, T., Zhang, R., Jiang, Y., Deng, C., Fu, Q., Hsu, N. C., and Cao, B.: Typical types and formation mechanisms of haze in an Eastern Asia megacity, Shanghai, Atmos. Chem. Phys., 12, 105-124, doi:10.5194/acp-12-105-2012, 2012.

Lei, Y., Zhang, Q., He, K. B., and Streets, D. G.: Primary anthropogenic aerosol emission trends for China, 1990-2005, Atmos. Chem. Phys., 11, 931-954, doi:10.5194/acp-11-931-2011, 2011.

Lin, G.: Globalization of the automobile industry in China: dynamics and barriers in greening of the road transportation, Energ. Policy, 31, 537-551, 2003.

Lin, Y. F. et al.: Air quality over the Yangtze River Delta during the 2010 Shanghai Expo, to be submitted, 2012.

Magee-Scientific: The Aethalometer, Magee Scientific Company, Berkeley, California, USA, 2005.

Malm, W. C., Sisler, J. F., Huffman, D., Eldred, R. A., and Cahill, T. A.: Spatial and Seasonal Trends in Particle Concentration and Optical Extinction in the United-States, J. Geophys. Res.Atmos., 99, 1347-1370, 1994.

Peundorf, R.: Tables of the refractive index for standard and the Rayleigh scattering coefficient for the spectral region between 0.2 and 20.0 microns and their application to atmospheric optics, J. Opt. Soc. Am., 47, 176-182, 1957.
Ramana, M. V., Ramanathan, V., Feng, Y., Yoon, S. C., Kim, S. W., Carmichael, G. R., and Schauer, J. J.: Warming influenced by the ratio of black carbon to sulphate and the black-carbon source, Nat. Geosci., 3, 542-545, 2010.

SMSB: Shanghai Municipal Statistics Bureau, Shanghai sixth national census in 2010 Communiqué on Major Data, Shanghai Municipal Statistics Bureau, available at: http://www.shanghai.gov.cn/shanghai/node2314/node2319/ node12344/u26ai25463.html, 2011 (in Chinese).

Sun, Y. L., Zhuang, G. S., Ying, W., Han, L. H., Guo, J. H., Mo, D., Zhang, W. J., Wang, Z. F., and Hao, Z. P.: The air-borne particulate pollution in Beijing - concentration, composition, distribution and sources, Atmos. Environ., 38, 5991-6004, 2004.

Tan, M. G., Zhang, G. L., Li, X. L., Zhang, Y. X., Yue, W. S., Chen, J. M., Wang, Y. S., Li, A. G., Li, Y., Zhang, Y. M., and Shan, Z. C.: Comprehensive study of lead pollution in Shanghai by multiple techniques, Anal. Chem., 78, 8044-8050, 2006.

Turpin, B. J. and Lim, H. J.: Species contributions to $\mathrm{PM}_{2.5}$ mass concentrations: Revisiting common assumptions for estimating organic mass, Aerosol Sci. Technol., 35, 602-610, 2001.

UNEP: UNEP Environmental Assessment: Expo 2010 - Shanghai, China, 2009.

USEPA: Quality assurance handbook for air pollution measurement systems, EPA-454/R-98-004, US Environmental Protection Agency, Office of Air Quality Planning and Standards, Air Quality Assessment Division, Research Triangle Park, N.C., 1998.

Vaisala: Weather Sensor FD12P User's Guide, Vaisala Oyj, Helsinki, Finland, 2002.

van $\operatorname{der}$ A, R. J., Peters, D. H. M. U., Eskes, H., Boersma, K. F., Van Roozendael, M., De Smedt, I., and Kelder, H. M.: Detection of the trend and seasonal variation in tropospheric $\mathrm{NO}_{2}$ over China, J. Geophys. Res., 111, D12317, doi:10.1029/2005JD006594, 2006.

Wang, S. X., Xing, J., Jang, C., Zhu, Y., Fu, J. S., and hao, J. M.: Impact Assessment of Ammonia Emissions on Inorganic Aerosols in East China Using Response Surface Modeling Technique, Environ. Sci. Technol., 45, 9293-9300, doi:10.1021/es2022347, 2011.

Wang, S. X., Zhao, M., Xing, J., Wu, Y., Zhou, Y., Lei, Y., He, K. B., Fu, L. X., and Hao, J. M.: Quantifying the Air Pollutants Emission Reduction during the 2008 Olympic Games in Beijing, Environ. Sci. Technol., 44, 2490-2496, 2010.

Wang, Y., Zhuang, G. S., Xu, C., and An, Z. S.: The air pollution caused by the burning of fireworks during the lantern festival in Beijing, Atmos. Environ., 41, 417-431, 2007.

Wang, Y., Zhuang, G. S., Zhang, X. Y., Huang, K., Xu, C., Tang, A. H., Chen, J. M., and An, Z. S.: The ion chemistry, seasonal cycle, and sources of $\mathrm{PM}_{2.5}$ and TSP aerosol in Shanghai, Atmos. Environ., 40, 2935-2952, 2006.

Xu, J., Bergin, M. H., Yu, X., Liu, G., Zhao, J., Carrico, C. M., and Baumann, K.: Measurement of aerosol chemical, physical and radiative properties in the Yangtze delta region of China, Atmos. Environ., 36, 161-173, 2002.

Yuan, H., Wang, Y., and Zhuang, G. S.: Simultaneous determination of organic acids, methanesulfonic acid and inorganic anions in aerosol and precipitation samples by ion chromatography, Journal of Instrumental Analysis, 22, 11-44, 2003.

Zhang, Q., Streets, D. G., Carmichael, G. R., He, K. B., Huo, H., Kannari, A., Klimont, Z., Park, I. S., Reddy, S., Fu, J. S., Chen, 
D., Duan, L., Lei, Y., Wang, L. T., and Yao, Z. L.: Asian emissions in 2006 for the NASA INTEX-B mission, Atmos. Chem. Phys., 9, 5131-5153, doi:10.5194/acp-9-5131-2009, 2009.

Zhang, Q. H., Zhang, J. P., and Xue, H. W.: The challenge of improving visibility in Beijing, Atmos. Chem. Phys., 10, 78217827, doi:10.5194/acp-10-7821-2010, 2010.

Zhang, Y. P., Wang, X. F., Chen, H., Yang, X., Chen, J. M., and Allen, J. O.: Source apportionment of lead-containing aerosol particles in Shanghai using single particle mass spectrometry, Chemosphere, 74, 501-507, 2009.
Zhao, Y., Wang, S. X., Duan, L., Lei, Y., Cao, P. F., and Hao, J. M.: Primary air pollutant emissions of coal-fired power plants in China: Current status and future prediction, Atmos. Environ., 42, 8442-8452, 2008.

Zhuang, G. S., Guo, J. H., Yuan, H., and Zhao, C. Y.: The compositions, sources, and size distribution of the dust storm from China in spring of 2000 and its impact on the global environment, Chinese Sci. Bull., 46, 895-901, 2001. 